\title{
An annotated checklist of the mammals of Paraguay
}

\author{
Noé U. de la Sancha ${ }^{1,2^{*}}$ Cella López-Gonzalezz ${ }^{3}$, Guillermo D’Elía ${ }^{4}$, Philip Myers ${ }^{5}$, Lourdes Valdez, ${ }^{6}$ and María Luisa Ortiz \\ ${ }^{1}$ Chicago State University, Department of Biological Sciences, 9501 S King Drive, Chicago 60628. Ilinois, United States. Email: \\ delasancha@msn.com (NDLS). \\ ${ }^{2}$ The Field Museum of Natural History, Integrative Research Center, 1400 S Lake Shore Dr., Chicago 60605. Ilinois, United States (NDLS). \\ ${ }^{3}$ Instituto Politécnico Nacional, CIIDIR Unidad Durango, Calle Sigma 119 Fracc. 20 de Noviembre II, CP. 34220, Durango. Durango, \\ México. Email: celialg@prodigy.net.mx (CLG). \\ ${ }^{4}$ Universidad Austral de Chile, Facultad de Ciencias, Instituto de Ciencias Ambientales y Evolutivas. Valdivia, Chile. Email: guille. \\ delia@gmail.com (GD) \\ ${ }_{5}^{5}$ Museum of Zoology, Research Museums Center, 3600 Varsity Drive, Ann Arbor 48108. Michigan, United States. Email: pmyers@ \\ umich.edu (PM) \\ ${ }^{6}$ Universidad Austral de Chile, Facultad de Ciencias, Doctorado en Ciencias mención Ecología y Evolución.. Valdivia, Chile. Email: \\ louvald@gmail.com (LV) \\ ${ }^{7}$ Itaipu Binacional, Centro de Investigación de Animales Silvestres, Dirección de Coordinación Ejecutiva. Hernandarias, Paraguay. \\ mariaortizfleitas@gmail.com (MLO) \\ *Corresponding author
}

As the center of convergence of some of the major bioregions of South America, Paraguay is a biodiverse country of biogeographic importance. Yet despite a long history of natural history research, basic knowledge of its fauna, including mammals, is still lacking. The last updated list of Paraguayan mammals was published in 2002, but increased research efforts since that time have brought about numerous changes in the taxonomy and known distribution of many species. We present an updated and annotated checklist on the mammals of Paraguay through 2016. Only species records based on the assessment of some type of verifiable voucher are included here. Because the Paraguay River has been considered a significant biogeographic boundary, the distribution of each species (east of the river, west of the river, present on both sides) is tabulated as well. We recorded 181 native species of mammals, 30 more than in 2002, belonging to 10 orders, 33 families, and 116 genera. Chiroptera (58) was the most diverse order, followed by Rodentia (56), Carnivora (20) and Didelphimorphia (18). Ctenomys pilarensis, C. paraguayensis y C. dorsalis are known only from Paraguay. The inventory is likely incomplete, as well as our knowledge of species distributional limits. Continued collecting of tissues and vouchers, as well as an examination of museum specimens, is necessary to address numerous unsolved questions concerning distribution, taxonomy, ecology, biogeography, population biology and the effects of anthropogenic modification.

Paraguay, localizado en el centro sur de América del Sur, incluye dentro de sus límites algunas de las grandes ecorregiones del continente. A pesar de una larga historia de investigación mastozoológica, el conocimiento básico sobre los mamíferos de Paraguay es aún escaso. El último listado actualizado de especies se publicó en 2002; a partir de entonces se han realizado numerosos cambios taxonómicos y ajustes distribucionales. En este trabajo se presenta una lista de los mamíferos nativos de Paraguay actualizada a 2016 con base en investigación bibliográfica. Sólo se incluyeron en la lista especies nativas cuya ocurrencia en Paraguay fuese respaldada por la evaluación de algun voucher verificable. Dado que el río Paraguay se ha considerado un límite biogeográfico relevante (oriente y occidente del Paraguay), se registró la ocurrencia de las especies en cada una de estas regiones. Se contabilizaron 181 especies nativas (30 más que en 2002) pertenecientes a 10 órdenes, 33 familias y 116 géneros. Chiroptera (58) fue el orden más diverso, seguido por Rodentia (56), Carnivora (20) y Didelphimorphia (18). Ctenomys pilarensis, C. paraguayensis y C. dorsalis se conocen sólo de Paraguay. El inventario es probablemente aún incompleto, así como las distribuciones de muchas especies son todavía inciertas. Es preciso continuar con la colecta en campo de ejemplares y tejidos, así como el estudio de colecciones de museo, con el fin de abordar vacios de conocimiento sobre distribución, taxonomía, ecología, biogeografía y el efecto de las modificaciones antrópicas sobre la mastrofauna.

Keywords: biogeography; distribution; nomenclature; Paraguay; Mammalia; South America; taxonomy

(C) 2017 Asociación Mexicana de Mastozoología, www.mastozoologiamexicana.org

\section{Introduction}

Paraguay is a landlocked country nested among Argentina, Bolivia, and Brazil in the Southern Cone of South America. While its topography is generally flat, a few hills ranging from $50 \mathrm{~m}$ to a maximum of $759 \mathrm{~m}$ above sea level are located primarily in the eastern portion of the country (Gorham 1973; Bartrina 2007). Because of its geographic position in the middle of South America, several major biomes of the continent (Cerrado, Chaco, Pantanal, and Atlantic Forest) extend into Paraguay, resulting in a more diverse flora and fauna than expected given the country's relatively small area and shallow topographic relief.

Paraguayan borders are delineated mainly by rivers, including the Paraná, Pilcomayo, and Paraguay. The center of the country lies on the Tropic of Capricorn at the interface between temperate and tropical zones. Paraguay's climate is characterized as tropical continental with six regional climates (Fariña 1973) and follows a continuum from semiarid at the northwestern border, where rainfall averages around $400 \mathrm{~mm}$ annually, to semitropical in the southeast, where annual rainfall is around $1,800 \mathrm{~mm}$. Average annual temperatures vary from $25.9{ }^{\circ} \mathrm{C}$ in the NW to $21.4{ }^{\circ} \mathrm{C}$ in the SE 
(Fariña 1973). The Paraguay River bisects the country from north to south into eastern and western regions that are distinctive geologically, ecologically, and faunistically (Myers 1982; Hayes 1995; Myers et al. 2002; López-González 2004).

Paraguay was the site of some of the earliest explorations of the Americas (Sainz Ollero et al. 1989), and it has played an important role in the history of South American mammalogy. The work of Félix de Azara (Azara 1801, 1802) supplied descriptions that are the basis of numerous currently recognized taxa, many of which are widely-distributed mammalian species. A total of six currently recognized marsupial (Gardner 2008a), two armadillo (Gardner 2008a), one felid, two canid (Wozencraft 2005), three primate (Groves 2005), two cervid (Grubb 2005), seven bat (López-González 2005; Simmons 2005), and 17 rodent species (Patton et al. 2015) have been described based on Paraguayan specimens.

Despite the long history of mammalogy in Paraguay, the country's mammal assemblage remains among the least studied in South America (Pine 1982; Myers et al. 2002). During the past 20 years, however, research on Paraguayan mammals has intensified (see a recent summary in LópezGonzález et al. 2014). A large number of species has been added recently to the Paraguayan fauna, information on species distributions has improved, and the natural history of some species is better known. In this work we provide an updated list of the mammals of Paraguay that reflects recent taxonomic advances and additions to the fauna.

\section{Methods and Materials}

Species list. We used the species list of Myers et al. (2002) as the starting point for a revised list of the mammalian fauna of the country. Because there was a delay of several years between the submission of the manuscript of Myers et al. (2002) and the actual publication of the work, papers published between 1997 and 2002 were not cited in that publication; therefore, those publications on species occurrences were included in this account. We used the list of Myers et al. (2002) instead of that of Rumbo (2010) because the latter is based mostly on a previous list by Gamarra de Fox and Martin (1996) with few additions. Similarly, the list by Neris (1998) only included records to 1993. Annotations to the list published here include new species records for the country (NSRC), taxonomic revisions and or nomenclature clarifications (TXNM), updated species distribution east or west of the Rio Paraguay (DIST), and subspecific status of populations when available (SSP).

A species was included in the list only if it could be traced to a published record associated with museum specimens, sequences, photographs, or other types of verifiable vouchers. Verification of literature records by actual examination of specimens (including photographs) is much needed but far beyond the scope of this report; it is our intent to provide a useful platform for such study. Nomenclature and taxonomic arrangement to subfamily level follows Wilson and Reeder (2005) with the following exceptions: for Cetartiodactyla we follow Agnarsson and May-Collado (2008) and Vislobokova (2013); for Cingulata, Gibb et al. (2016); and for Primates, Rylands and Mittermeier (2009). Genera and species are arranged in alphabetical order. Domestic or wild introduced species are not considered in the list.

\section{Results}

Updated checklist. Our search retrieved 181 native species of mammals (Table 1) that have been reported for Paraguay, representing 10 orders, 34 families, and 116 genera. The order Chiroptera was the most diverse (58 species), followed by Rodentia (56), Carnivora (20) and Didelphimorphia (18; Figure 1). At the family level, Cricetidae had the highest species richness (34), followed by Phyllostomidae (20), Didelphidae (18), Molossidae (17), Vespertilionidae (16), Dasypodidae (11), Felidae (8), Mustelidae (5), Echimyidae (5), and

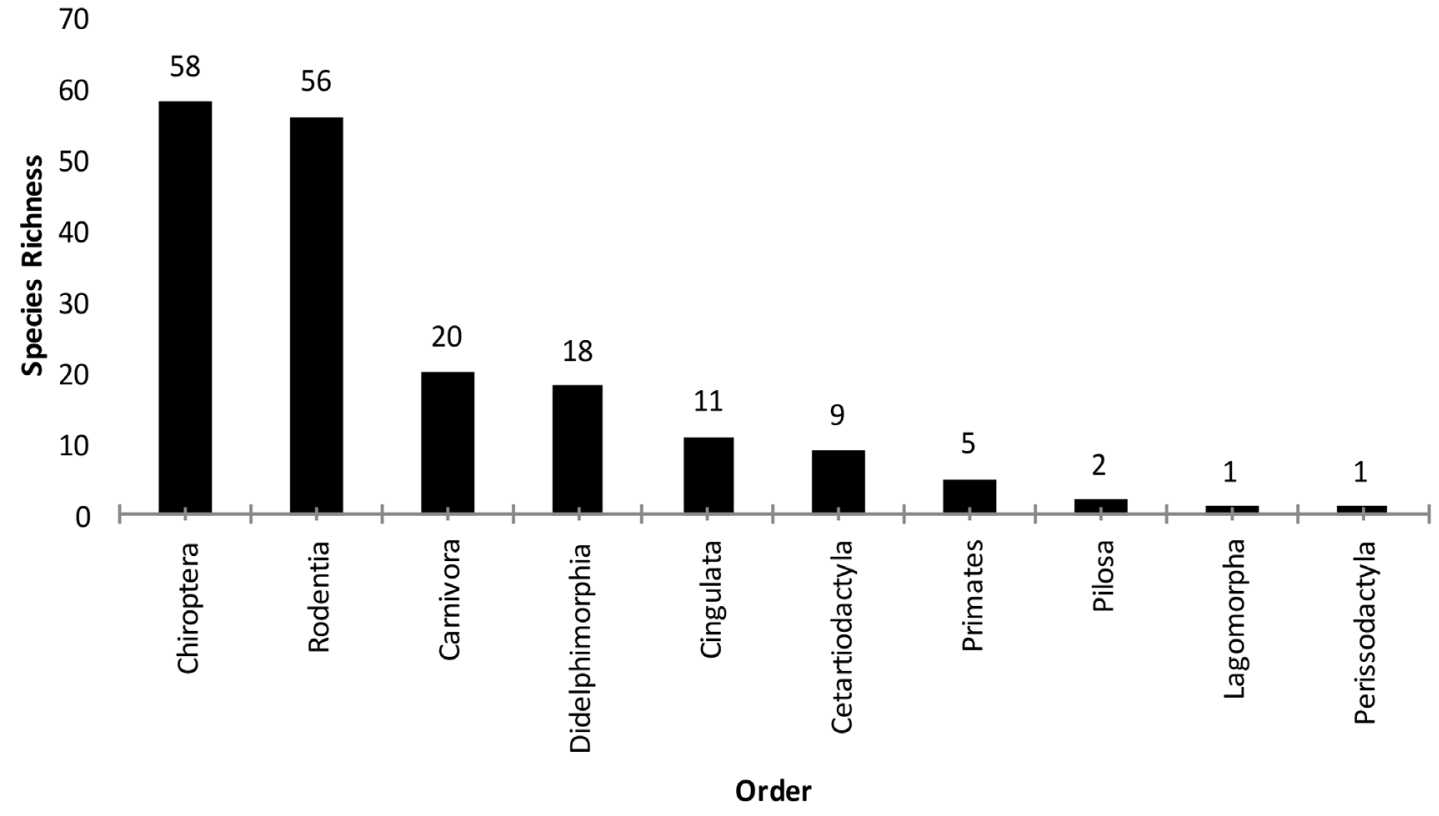

Figure 1. Paraguayan mammal species by order to 2016. 
Cervidae (5; Figure 2). All other families were represented by four or fewer species. Three species, Ctenomys pilarensis, C. paraguayensis, and C. dorsalis are known only from Paraguay (Bidau 2015). Subspecific names were available for 69 species. We documented 59 taxonomic or nomenclatural changes at the species level since Myers et al. (2002).

Myers et al. (2002) reported 156 species in their account, but we could not confirm the presence of Bradypus variegatus, Monodelphis scalops, or Ctenomys boliviensis in Paraguay. M. scalops reported in Myers et al. is a misidentified M. brevicaudis $=$ M. sorex (de la Sancha et al. 2007). Conepatus humboldti is now regarded as a synonym of $C$. chinga, both listed by Myers et al. (2002) as distinct species. The presence of Myotis levis was based on a report that was probably erroneous (Table 1). These changes reduced the list to 151 species. Here we document 30 additional species for the Paraguayan mammalian fauna (Table 1), either as new records or as populations formerly considered as one species but recently split into two, both occurring in Paraguay. Five of the additions are opossums, 10 are bats, 14 are rodents, and 1 is a carnivore. Three additional species, Anoura caudifer (López-González 2005), Dasypus septemcinctus (Wetzel et al. 2008), and Calomys callidus (SalazarBravo 2015) have been reported for Paraguay but no unambiguous records of their presence are available (Griffiths and Gardner 2008; Salazar-Bravo 2015) and therefore they are not included in our list.

Geographic distribution. We document 27 changes that either expand or restrict the distributions of species in eastern and western Paraguay reported by Myers et al. (2002). Of the total 181 species reported (Table 1), 58 (32.0\%) have been found only east of the Río Paraguay, 35 (19.3\%) only west of the river, and 88 (48.6\%) on both sides. Most mammalian Families include more species east of the Rio Paraguay, but one third have more species west of the river (Emballonuridae, Molossidae, Dasypodidae, Sciuridae, Caviidae, Tayassuidae, Camelidae, Callitrichidae, Aotidae, and Pitheciidae), although the difference in numbers between East and West assemblages is small (one or two species) within each of these families.

\section{Discussion}

Species richness. The first documentation of the Paraguayan mammal fauna dates to the earliest natural history explorations of South America in the $16^{\text {th }}$ century (reviewed by López-González et al. 2014), yet the Paraguayan fauna is still one of the most poorly understood in South America. In recent years, however, investigations focusing on the biology of Paraguayan mammals have accelerated. The 151 species reported by Myers et al. (2002); sent to publication in 1997) increased to 167 in the list by Neris (1998), and to 181 in this account, an increase of $19.9 \%$ from Myers et al. (2002) in less than 20 years. Species have been added due to new findings in the field, review of museum material, taxonomic revisions, and phylogenetic analyses (e. g., López-González et al. 1998; Willig et al. 2000; Voss et al. 2005, 2009; LópezGonzález 2005; Weksler and Bonvincino 2005; de la Sancha et al. 2007; D'Elía et al. 2008a, 2008b; Percequillo et al. 2008; de la Sancha et al. 2009; Voss et al. 2009; Stevens et al. 2010; de la Sancha et al. 2011; Bornholdt et al. 2013; de la Sancha 2014; González-Ittig et al. 2014; Moratelli and Wilson 2013; Owen et al. 2014; de la Sancha and D'Elía 2015; Moratelli et al. 2015; Timm et al. 2015; Pardiñas et al. 2016). The number of nomenclatural and taxonomic changes observed reflects an

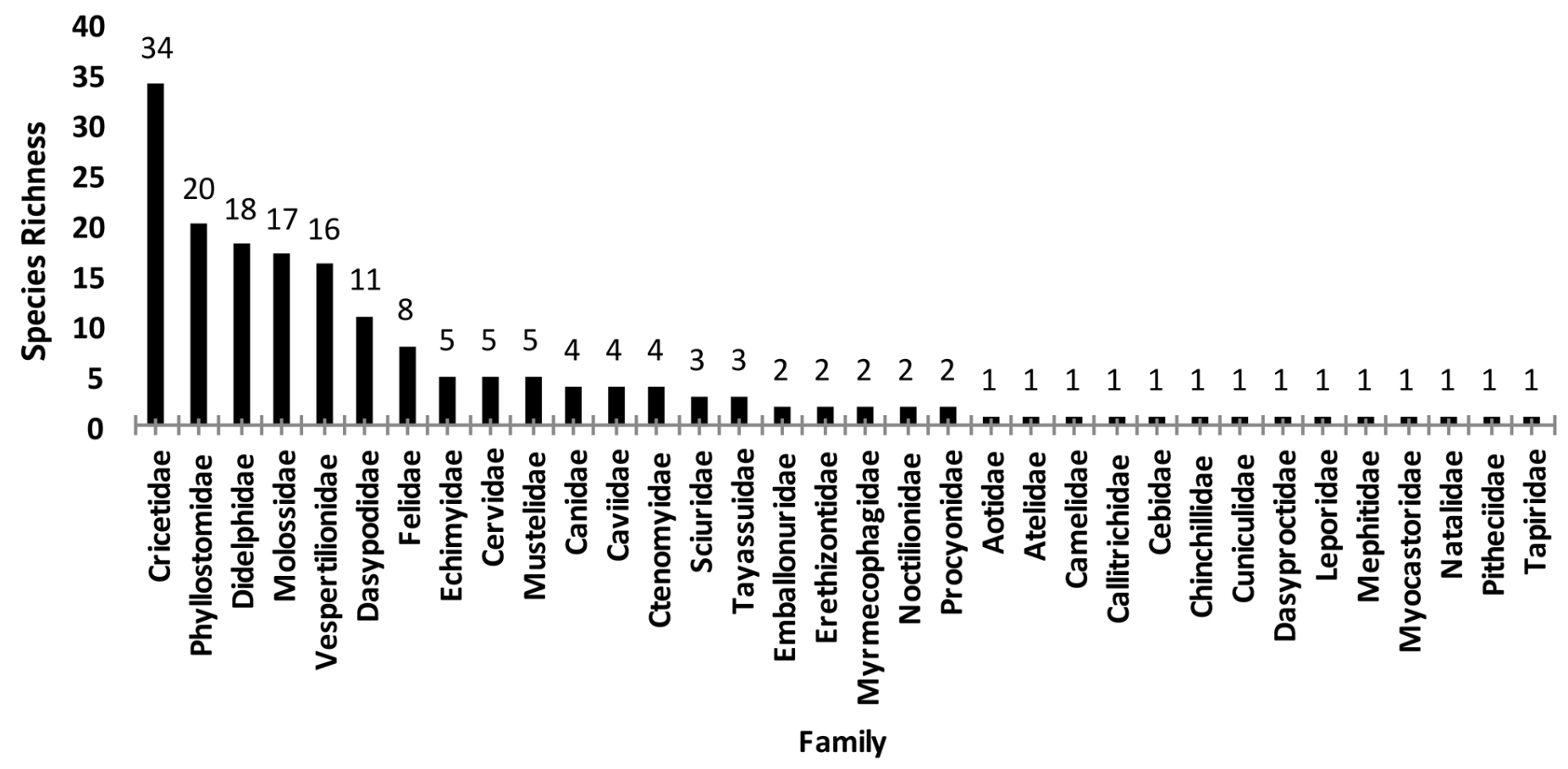

Figure 2. Paraguayan mammal species by family to 2016 . 
improving understanding of the diversity and phylogenetic relationships of the South American mammalian fauna in general, and the Paraguayan assemblage in particular. This body of work is improving our understanding of distributions at a finer scale for many species, particularly of small mammals, but less has been done on mid-size and large species. Continued field work, museum-based research, DNA barcoding, and raptor pellet examinations (i. e., Torres et al. 2014) likely will reveal the presence of undescribed species in the country as well as species currently known from adjacent areas of neighboring countries.

Probable species. Myers et al. (2002) reported the occurrence of Bradypus variegatus in Paraguay. Although it has been recorded from Misiones, Argentina (Gardner 2008b), and there are unconfirmed reports for Paraguay (Bertoni 1939), we are not aware of unequivocal evidence of its presence, although the species may occur, or may have occurred, in Paraguay. Anoura caudifer was included in the Paraguayan fauna by López-González (2005) based on a report by Podtiaguin (1944), but Griffiths and Gardner (2008) questioned this report, and no specimen of $A$. caudifer is available to confirm its presence in Paraguay. Salazar-Bravo (2015) reported Calomys callidus for Paraguay; although it is likely to occur in the humid Chaco following a distribution similar to that of several marsupials (de la Sancha and D'Elía 2015), we found no published evidence of its occurrence in Paraguay. Ctenomys boliviensis was included in Myers et al. (2002), but the only available records for the species are from the area around Santa Cruz, Bolivia (Bidau 2015).

Leopardus guttulus was reported by Johnson et al. (1999) and Trigo et al. (2008) to occur in the Paraguayan Chaco. However, a closer examination of their specimen lists raises doubts about the distribution of this species. Figure 1 in Johnson et al. (1999) includes a locality in the Chaco. In their list of examined material (Appendix 1) these authors report a sample (LTI 37) from Iguazu Paraguay, referring to the source of the sample as "Itaipu Paraguay." They also list a sample (LTI 38) from "Curuguaty, W. Paraguay," referring the source of the sample to "Itaipu Paraguay" as well. Iguazu is not in Paraguay and Curuguaty is not in Western Paraguay, making it impossible to determine where their samples came from. In their Figure 1A, Trigo et al. (2008) suggest the species is only found in Eastern Paraguay, but in their Figure 1B they report a site in the Paraguayan Chaco. Furthermore, in their Supporting Material, they state that the geographic origin of their sample is the Paraguayan Chaco. Because of these apparently conflicting reports, we list L. guttulus only for Eastern Paraguay but recognize that its distribution is poorly known and may eventually be shown to include Chacoan sites.

Dasypus septemcinctus has been reported to occur in Paraguay (Wetzel et al. 2008) but no specimen records were presented by those authors. We were unable to find other published records of this species and thus do not include it in Table 1.

\section{Current knowledge of major mammalian groups}

Didelphimorphia. Recent works have incorporated both morphological and genetic evidence to improve our understanding of the distribution and systematics of Paraguayan marsupials (Voss et al. 2005; de la Sancha et al. 2007; Teta et al. 2009; Voss et al. 2009; de la Sancha et al. 2012; Smith et al. 2012; Martínez-Lanfranco et al. 2014; Smith and Owen 2015; de la Sancha and D'Elía 2015). Five species of marsupials have been reported for Paraguay for the first time since 2005. Nonetheless, major gaps remain in our understanding of the natural history and ecology of Paraguayan marsupials.

Cingulata. Much of our understanding of the armadillo species present in Paraguay is based on the works of Wetzel (1980, 1985). Only one study has incorporated molecular data from Paraguayan populations (Frutos and Van Den Bussche 2002), and few investigations have addressed geographic distribution or conservation, a pressing concern given that armadillos are hunted for food (Smith et al. 2011; Weiler and Núñez 2012). Ecology, phylogenetics, conservation, and management themes provide valuable research opportunities for this group in Paraguay.

Pilosa. To our knowledge, no publication has focused exclusively on Paraguayan anteaters, even though they are common throughout the country. Research on distribution, ecology and natural history is urgently needed because of the extensive habitat conversion and loss currently occurring in Paraguay.

Primates. The taxonomy of Neotropical primates has changed considerably in the past few years, reflecting current research efforts focusing on the group across the South American continent. Although Paraguayan specimens have been used in regional studies including morphology (Arístide et al. 2014), genetics (Matayoshi et al. 1986; Mudry et al. 1987; Pargament and Slavutsky 1987; Martínez et al. 2004; Mudry et al. 2007; Casado et al. 2010), phylogenetics and phylogeography (Hoyos et al. 2016), ecology (Boyle 2014) and zoonosis (Díaz et al. 2007), little research has been done on this group within Paraguay; the few works available focus on rare or uncommon species such as Mico melanurus (Stallings and Mittermeier 1983), Aotus azarae (Campos et al. 2004), and on the more common Alouatta caraya (Giordano and Ballard 2010). Conservation status of primates in Paraguay was assessed by Stallings (1985) and Rumiz and Stallings (1989) and has not been revised since. Given the current rate of habitat loss, this charismatic fauna should be the focus of ecological and conservation studies.

Lagomorpha. Information on Paraguayan lagomorphs is scarce. The taxonomy of the Paraguayan populations is still unclear at best given that Sylvilagus brasiliensis is probably a species complex (Bonvicino et al. 2015) and is in need of revision. We found no literature focused on the biology of $S$. brasiliensis in Paraguay even though it is a common species throughout the country.

Chiroptera. Bats, with a total of 58 species, are the most species-rich order in Paraguay. López-Gonzalez (2005) sum- 
marized knowledge before 2000 of Paraguayan Chiroptera, listing 54 species based on specimens collected and deposited in collections. Since then, Myotis levis (Stevens et al. 2010), M. midastactus and Myotis "simus-like" (Moratelli et al. 2015), Saccopteryx leptura, and Gardnerycteris crenulatum (Owen et al. 2014) have been added to Paraguay's fauna, while Anoura caudifer has been removed from the list (see above). The inventory of bats is likely to grow as further field and revisionary research is conducted.

Recent non-taxonomic bat research in Paraguay has focused mainly on community ecology (Stevens et al. 2004; Gorresen et al. 2005; Presley 2007; Stevens et al. 2007; Presley et al. 2009; Presley 2012; Stevens and Amarilla-Stevens 2012), on relationships of bats with their ectobionts (Durette-Dusset and Vaucher 1999; Dick and Gettinger 2005; Graciolli et al. 2006; Heddergott 2008; Presley and Willig 2008), ecological biogeography (López-González 2004; Stevens et al. 2007), and conservation issues (Andelman and Willig 2002; Gorresen and Willig 2004). Little has been done on the natural history and ecology of individual species or Paraguayan populations with few exceptions (Stevens 2001; McCulloch and Stevens 2011; McCulloch et al. 2013; Stevens et al. 2016).

Carnivora. Paraguay is home to 20 species of carnivores, all occurring on both sides of the Rio Paraguay with the possible exceptions of Leopardus guttulus (see above) and Galictis vittata (see details Table 1). A finer scale analysis is needed to ascertain the specific habitats or bioregions that these organisms occupy. Additionally, their ecology and natural history in Paraguay has not been explored, and a number of taxonomic and nomenclatural issues have yet to be resolved. Considering that many medium and largesized carnivores are highly charismatic it is surprising to find so little research has been done on them.

Most studies on felids have focused primarily on jaguars and pumas (Taber et al. 1997; de Angelo et al. 2011a, 2011b; Giordano et al. 2014). Studies of other cats include only a few notes on medium sized species (Zuercher et al. 2001). For canids, there are few taxon-specific publications. Descriptive and conservation-related work is available for Chrysocyon brachyurus (Meritt 1973; Queirolo et al. 2011; Cartes et al. 2015). Ironically the most elusive canid in Paraguay, Speothos venaticus, is the best studied (Zuercher and Villalba 2002; Zuercher et al. 2003, 2005). Nonetheless, basic taxonomic, ecological, and distributional issues are yet to be resolved for Paraguayan populations of the bush dog. Beyond lists or locality records, studies of mustelids, mephitids, and procyonids are essentially non-existent. Carnivores in general represent a major knowledge gap in Paraguay and offer scientists a great opportunity for study.

Cetartiodactyla. Most of the nine species that occur in Paraguay are found on both sides of the Rio Paraguay, with the exception of Parachoerus wagneri and Lama guanicoe, both restricted to Western Paraguay, and Mazama nana, which is restricted to Eastern Paraguay. Until 1975, Para- choerus wagneri was known only from the fossil record; the discovery of this "living fossil" (Wetzel et al. 1975) precipitated a massive effort to document the biology of this species (Wetzel et al. 1975; Mayer and Brandt 1982; Benirschke et al. 1985; Mayer and Wetzel 1986; Byrd et al. 1988; Benirschke et al. 1989a, 1989b; Taber 1990; Handen and Benirschke 1991; Taber 1991; Brooks 1992; Taber 1993; Handen et al. 1994; Taber et al. 1993, 1994; Yahnke et al. 1997; Toone and Wallace 2002; Toone et al. 2003; Sutherland-Smith et al. 2004; Meritt 2010). Studies of other ungulates in Paraguay, however, have lagged far behind, and those species are known primarily from lists or reports of sightings. Of the five species of Paraguayan deer, only Mazama gouazoubira has been studied ecologically (Stallings 1984, 1986) whereas the guanaco (Lama guanicoae) is only known from a few sightings (Villalba and Bonacic 2006). Even the taxonomy of populations of common, medium-sized species like Mazama americana is uncertain in Paraguay. The name M. americana currently applies to populations of northern South America (Groves and Grubb 2011). The names M. rufa and $M$. jucunda are available for the Paraguayan populations (Groves and Grubb 2011), but no decision as to which applies is possible without revision of the pertinent materials. Here, we have opted to be conservative and kept the name Mazama sp. for Paraguayan populations of this species until such revision is available.

Perissodactyla. The few publications concerning Paraguayan tapirs deal with their use by indigenous people (Hill et al. 1997; Hill and Padwe 2000; Hill et al. 2003) and the effects that habitat changes are having on this species (Brooks et al. 1997). Many habitats in Paraguay have changed considerably since the late 1990s and therefore, this report is likely outdated. Paraguay is a potential contact zone for T. terrestris terrestris and T. t. spegazzinii; however, to date only T.t. terrestris is confirmed for the country (Groves and Grubb 2011). The possible occurrence of T. $t$. spegazzinii is currently an open research opportunity with taxonomic and population genetic implications.

Rodentia. Rodents are the most diverse order of mammals in the world (Carleton and Musser 2005). They comprise close to $50 \%$ of the mammal species in Central and South America (Patton et al. 2015), yet in Paraguay they appear to be somewhat less diverse than bats. We suggest that the apparent under-representation of rodents (or over-representation of bats) in the Paraguayan fauna is an artifact of inadequate sampling and lack of taxonomic study. Remarkably, since 2005 a new Family (Sciuridae), three genera (Sciurus, Bibimys, Juliomys) and 13 species of rodents (Table 1) have been reported for Paraguay for the first time. Many rodent groups continue to receive scant attention from systematists, and future taxonomic revisions are likely to result in the proportion of rodents in the Paraguayan fauna more closely reflecting proportions in faunas elsewhere.

A better understanding of the rodent fauna of Paraguay is critical. Rodents and other small mammals play important ecological roles, including seed predators, consumers 
of insects including possible crop pests, and as prey base for a large community of mammalian, avian and reptilian predators. They are valuable in ecological studies, including those concerning anthropogenic disturbance such as landscape and climate change (de la Sancha 2014; de la Sancha et al. 2014). Rodents are also important hosts for human pathogens, including hantaviruses, which are known from Paraguay (Yahnke et al. 2001; Chu et al. 2003, 2006; Goodin et al. 2006; Padula et al. 2007; Chu et al. 2009; Goodin et al. 2009). Studies dealing with population dynamics of rodents in Paraguay have been severely handicapped by lack of field identification tools; reliable keys and much more basic work are still needed in Paraguay.

Our review of publications in the preparation of Table 1 revealed the following major trends:

1. Most publications are still fundamentally descriptive works, mostly taxonomic and distributional. Chiroptera, Didelphimorphia, and Rodentia are the most-studied taxa, but research efforts even within these groups have focused on a few species and mostly on distributional, taxonomic, and systematic issues. Other aspects of the Paraguayan mammalian fauna are very poorly studied.

2. The basic taxonomy of many medium-sized and large mammal species is poorly understood at best. Few Paraguayan specimens of most medium-sized and large species are available, and because many of these animals are threatened or endangered, further collection of samples is expected to be limited. However, as new sampling methods are devised and processing costs decrease with the application of new molecular techniques, non-lethal sampling is becoming more effective and affordable. Also, developments in tracking technology and camera trapping make possible new kinds of studies of natural history and distribution. Many opportunities for work on larger mammals exist, and this kind of research is urgently needed.

3. Our inventory of Paraguayan mammals is likely incomplete, as is our knowledge of species distributional limits within Paraguay. Particularly for rodents, no comprehensive review is available, and field identifications are problematic. Considerable collections already exist in several museums across the world, but critical study of many of these specimens, further collection of selected species, and surveys of critical areas remain to be done. DNA barcoding will play a role, but the usefulness of this technique rests on the association of tissue samples with properly identified, well curated, and accessible vouchers.

4. Very few studies at the population, community or metacommunity levels are available. Conservation assessment and management strategies exist only for a handful of species or for restricted protected areas. Conservationoriented research is urgent given the accelerated rate of environmental modification currently affecting Paraguay.

5. Paraguay is located in the heart of South America and at the intersection of several major South American ecoregions. Yet, for many biological groups, Paraguay represents a knowledge gap between Brazil, Argentina, and Bolivia. Further local and regional research will narrow this gap, thus providing better understanding of large-scale biogeographical and evolutionary processes. For instance, there is still much to understand about the role of the Rio Paraguay as a dispersal filter or barrier between major biomes, not only within Paraguay but at a larger scale.

6. Improved understanding of the Paraguayan fauna is vital to understand the impacts of anthropogenic changes.

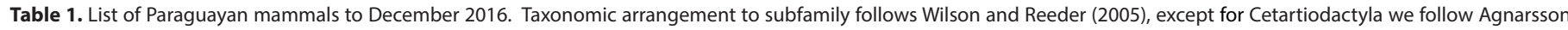

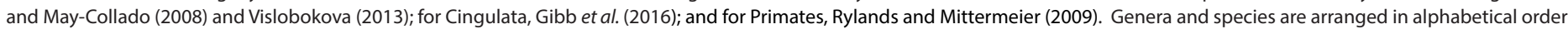

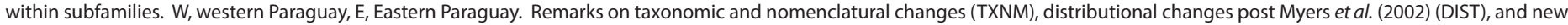
species records (NSRC) since Myers et al. (2002) are included when applicable. SSP: subspecific epithet and reference of paper where the subspecies is recognized, PY: Paraguay.

\begin{tabular}{|c|c|c|c|}
\hline Species & w & $\mathbf{E}$ & Remarks \\
\hline \multicolumn{4}{|l|}{ Order Didelphimorphia } \\
\hline \multicolumn{4}{|l|}{ Family Didelphidae } \\
\hline \multicolumn{4}{|l|}{ Subfamily Caluromyinae } \\
\hline Caluromys lanatus (Olfers, 1818) & & $x$ & SSP: lanatus, Gardner (2008c). \\
\hline \multicolumn{4}{|l|}{ Subfamily Didelphinae } \\
\hline Chironectes minimus (Zimmermann, 1780) & & $x$ & SSP: paraguensis, Stein and Patton (2008). \\
\hline Cryptonanus chacoensis (Tate, 1931) & $x$ & $x$ & $\begin{array}{l}\text { NSRC: Voss et al. } 2005 \\
\text { DIST: on both sides of PY River (de la Sancha and D'Elía 2015). }\end{array}$ \\
\hline Cryptonanus unduaviensis (Tate, 1931) & $x$ & & NSRC: de la Sancha and D’Elía (2015). \\
\hline Didelphis albiventris (Lund 1840) & $x$ & $x$ & SSP: leucotis, Cerqueira and Tribe (2008). \\
\hline Didelphis aurita (Wied-Neuwied, 1826) & & $x$ & $\begin{array}{l}\text { TXNM: D. azarae Temminck } 1824 \text { predates current name but Cerqueira and Tribe (2008) } \\
\text { retained aurita to minimize confusion in literature. }\end{array}$ \\
\hline Gracilinanus agilis (Burmeister, 1854) & & $x$ & \\
\hline Lutreolina crassicaudata (Desmarest, 1804) & $x$ & $x$ & SSP: crassicaudata, Martínez-Lanfranco et al. (2014). \\
\hline Marmosa constantiae (Thomas, 1904) & $\mathrm{x}$ & $x$ & $\begin{array}{l}\text { NSRC: Voss et al. (2009) } \\
\text { DIST: reported for W PY by de la Sancha et al. (2012) }\end{array}$ \\
\hline Marmosa paraguayana (Tate, 1931) & & $x$ & TXNM: as Micoureus demerarae in Myers et al. (2002), updated by Voss and Jansa (2009). \\
\hline
\end{tabular}


Metachirus nudicaudatus (É. Geoffroy, 1803)

Monodelphis domestica (Wagner, 1842)

Monodelphis kunsi Pine, 1975

Philander frenatus (Olfers, 1818)

Philander opossum (Linnaeus, 1758)

Thylamys macrurus (Olfers, 1818)

Thylamys pusillus (Desmarest, 1804)
Monodelphis brevicaudis (Erxelben, 1777)

TXNM: as Monodelphis sorex in Myers et al. (2002), updated by Solari (2010) and de la Sancha and D'Elía (2015).
X

\section{Order Cingulata}

Family Dasypodidae

\section{Subfamily Dasypodinae}

Dasypus hybridus (Desmarest, 1804)

Dasypus novemcinctus Linnaeus, 1758

\section{Subfamily Euphractinae}

Calyptophractus retusus (Burmeister, 1863)

Chaetophractus vellerosus (Gray, 1865)

Chaetophractus villosus (Desmarest, 1804)

Euphractus sexcinctus (Linnaeus, 1758)

\section{Subfamily Tolypeutinae}

Cabassous chacoensis Wetzel, 1980

Cabassous tatouay (Desmarest, 1804)

Cabassous unicinctus (Linnaeus, 1758)

Priodontes maximus (Kerr, 1792)

Tolypeutes matacus (Desmarest, 1804)

Order Pilosa

Family Myrmecophagidae

Myrmecophaga tridactyla Linnaeus, 1758

Tamandua tetradactyla (Linnaeus, 1758)

\section{Order Primates}

Family Callitrichidae

Mico melanurus (É. Geoffroy, 1812)

\section{Family Cebidae}

Subfamily Cebinae

Sapajus cay (Illiger, 1815)

\section{Family Aotidae}

Aotus azarae (Humboldt, 1811)

Family Pitheciidae

Subfamily Callicebinae

Plecturocebus pallescens Thomas 1907

\section{Family Atelidae}

Subfamily Alouattinae

Alouatta caraya (Humboldt, 1812)
NSRC: de la Sancha et al. (2007).

X TXNM: as P. opossum in Myers et al. (2002) DIST: E PY only (Patton and da Silva 2008).

X NSRC: de la Sancha and D'Elía (2015).

TXNM: name applied by Patton and da Silva (1997) to populations of central South America not including PY.

SSP: canus, Chemisquy and Flores (2012).

X TXNM: as T. macrura in Myers et al. (2002), updated by Voss et al. (2009). DIST: Myers et al. (2002) reports it in E and W PY, restricted to E PY by Voss et al. (2009).

TXNM: as T. pusilla in Myers et al. (2002), updated by Voss et al. (2009) and Teta et al. (2009).

DIST: Myers et al. (2002) reports it for E and W PY, restricted to W PY by Voss et al. (2009)

X DIST: Myers et al. (2002) reports it for $E$ and W, but no western Paraguayan specimens are available (Wetzel et al. 2008, Smith 2012).

SSP: novemcinctus, Wetzel et al. (2008)

SSP: tatouay, Wetzel et al. (2008).

TXNM: Family clarification by Rylands and Mittermeier (2009).

TXNM: as Callithrix argentata in Myers et al. (2002), updated by Stallings and Mittermeier (1983) and Rylands et al. (2008).

TXNM: Subfamily clarification by Rylands and Mittermeier (2009). TXNM: as Cebus apella in Myers et al. (2002), updated by Lynch Alfaro et al. (2012).

TXNM: Family clarification by Rylands and Mittermeier (2009).

TXNM: as Aotus azarai in Myers et al. (2002), updated by Groves (2005).

TXNM: Family and subfamily clarification by Rylands and Mittermeier (2009).

TXNM: as Callicebus donacophilus in Myers et al. (2002), species clarification updated in Groves (2005), and family and generic clarification updated by Byrne et al. (2016).

TXNM: Family and subfamily clarification by Rylands and Mittermeier (2009).

Order Lagomorpha

Family Leporidae 
Sylvilagus brasiliensis (Linnaeus, 1758)

\section{Order Chiroptera}

Family Emballonuridae

Subfamily Emballonurinae

Peropteryx macrotis (Wagner, 1843)

Saccopteryx leptura (Schreber, 1774)

Family Phyllostomidae

Subfamily Desmodontinae

Desmodus rotundus (É. Geoffroy, 1810)

Diaemus youngi (Jentnik, 1893)

\section{Subfamily Glossophaginae}

Glossophaga soricina (Pallas, 1776)

\section{Subfamily Phyllostominae}

Chrotopterus auritus (Peters, 1856)

Lophostoma brasiliense (Peters, 1866)

Lophostoma silvicolum D'Orbigny, 1836

Macrophyllum macrophyllum (Schinz, 1821)

Gardnerycteris crenulatum (E. Geoffroy St.-Hilaire 1803)

Phyllostomus discolor (Wagner, 1843)

Phyllostomus hastatus (Pallas, 1767)

Tonatia bidens (Spix, 1823)

\section{Subfamily Carolliinae}

Carollia perspicillata (Linnaeus, 1758)

\section{Subfamily Stenodermatinae}

Artibeus fimbriatus Gray, 1838

Artibeus lituratus (Olfers, 1818)

Artibeus planirostris Spix, 1823

Chiroderma doriae Thomas, 1891

Platyrrhinus lineatus (É. Geoffroy, 1810)

Pygoderma bilabiatum (Wagner, 1843)

Sturnira lilium (É. Geoffroy, 1810)

Vampyressa pusilla (Wagner, 1843)

\section{Family Noctilionidae}

Noctilio albiventris Desmarest, 1818

Noctilio leporinus (Linnaeus, 1758)

\section{Family Natalidae}

Natalus macrourus (Gervais, 1856)

\section{Family Molossidae}

\section{Subfamily Molossinae}

Cynomops abrasus (Temminck, 1827)

Cynomops planirostris (Peters, 1866)

Eumops auripendulus (Shaw, 1800)

Eumops bonariensis (Peters, 1874)

Eumops dabbenei Thomas, 1914

Eumops glaucinus (Wagner, 1843)

Eumops patagonicus Thomas, 1924

Eumops perotis (Schinz, 1821)

Molossops temminckii (Burmeister, 1854)

Molossus currentium Thomas, 1901
TXNM: very likely a species complex (Bonvicino et al. 2015).

SSP: paraguensis, Bonvicino et al. (2015). $x$

$\mathrm{X}$

SSP: rotundus, Kwon and Gardner (2008)

rted by Myers

$x$

$x \quad x$

$x$

$\mathrm{X}$

$X$

$x$

$\mathrm{X}$

$X$

SSP: cabrerai, Gardner (2008f).

SSP: rufescens, Gardner (2008f).
SSP: tricolor, McLellan and Koopman (2008).

NSRC: López-González et al. (1998) as Tonatia brasiliense

SSP: silvicolum, Williams and Genoways (2008). TXNM: as Tonatia silvicola in Myers et al. (2002).

NSRC: Owen et al. (2014).

TXNM: As Mimon in Owen et al. (2014), updated by Hurtado and Pacheco (2014).

DIST: Reported by Myers et al. (2002) for E PY but specimens available for W PY only (López-González 2005).

SSP: hastatus, Williams and Genoways (2008).

SSP: lituratus, Marques-Aguiar (2008).

SSP: planirostris, Marques-Aguiar (2008).

NSRC: López-González et al. (1998).

SSP: bilabiatum, Gardner (2008d).

SSP: lilium, Gardner (2008e), Velazco and Patterson (2013).

TXNM: as Natalus sp. in Myers et al. (2002), updated by Garbino and Tejedor (2013). 
Molossus molossus (Pallas, 1766)

Molossus rufus É. Geoffroy, 1805

Nyctinomops laticaudatus (E. Geoffroy, 1805)

Nyctinomops macrotis (Gray, 1840)

Promops centralis Thomas, 1915

Promops nasutus (Spix, 1823)

Tadarida brasiliensis (I. Geoffroy, 1824)

\section{Family Vespertilionidae}

\section{Subfamily Vespertilionidae}

Eptesicus brasiliensis (Desmarest, 1819)

Eptesicus diminutus (Osgood, 1915)

Eptesicus furinalis (d'Orbigny, 1847)

Histiotus macrotus (Poeppig, 1835)

Histiotus velatus (I. Geoffroy, 1824)

Lasiurus blossevillii (Lesson, 1826)

Lasiurus cinereus (Palisot de Beauvois, 1796)

Lasiurus ega (Gervais, 1856)

Myotis albescens (E. Geoffroy, 1806)

Myotis lavali (Moratelli et al. 2011)

Myotis levis (I. Geoffroy, 1824)

Myotis midastactus Moratelli and Wilson, 2014

Myotis nigricans (Schinz, 1821)

Myotis riparius Handley, 1960

Myotis ruber (E. Geoffroy, 1806)

Myotis "simus-like"

\section{Order Carnivora}

\section{Family Felidae}

\section{Subfamily Felinae}

Leopardus braccatus (Cope, 1889)

Leopardus geoffroyi (d'Orbigny and Gervais, 1844)

Leopardus guttulus (Hensel, 1872)

Leopardus pardalis (Linnaeus, 1758)

Leopardus wiedii (Schinz, 1821)

Puma concolor (Linnaeus, 1771)

Puma yagouaroundi (É. Geoffroy-Saint-Hilaire, 1803)

Subfamily Pantherinae

Panthera onca (Linnaeus, 1758)

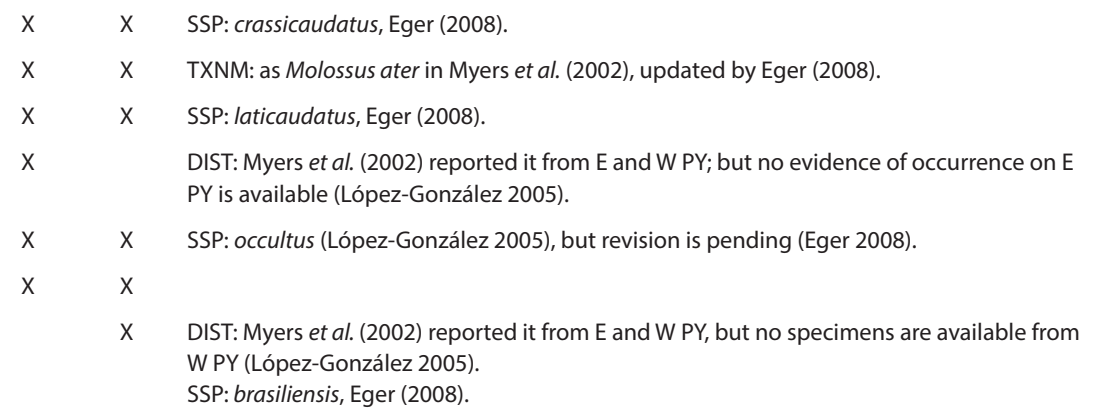

X DIST: Reported for W PY by Myers et al. (2002) and Davis and Gardner (2008), but specimens on which these reports are based are morphologically E. furinalis (López-González et al. 2005). SSP: brasiliensis, Davis and Gardner (2008).

$X$

$\mathrm{X}$

$X$

$\mathrm{X}$

$X$

$x$

$X$

$X$

X DIST: Reported for E and W PY by López-González (2005).

SSP: fidelis, Davis and Gardner (2008).

X SSP: furinalis, Davis and Gardner (2008).

NSRC: López-González et al. (1998).

X DIST: Myers et al. (2002) reported it from E and W PY, but no specimens from W PY are available (López-González 2005).

X SSP: blossevillii, Gardner and Handley (2008).

TXNM: as L. borealis in Myers et al. (2002), updated by Gardner and Handley (2008).

SSP: villosissimus, Gardner and Handley (2008).

SSP: argentinus, Gardner and Handley (2008).

NSRC: Moratelli and Wilson (2013)

NSRC: Stevens et al. (2010).

DIST: included in Myers et al. (2002) based on mis-identified specimens (Stevens et al.

2010).

SSP: levis (Wilson 2008), but Bárquez (2006) elevated subspecies of $M$. levis to species $M$. levis and M. dinellii (not in PY).

NSRC: Moratelli et al. (2015)

TXNM: as M. simus (in part) in Myers et al. (2002), updated by Moratelli et al. (2015). SSP: nigricans, Davis and Gardner (2008)

TXNM: reported in part as M. simus (Myers et al. 2002, López-González 2005). DIST: Moratelli et al. (2015).
$X$

TXNM: as Oncifelis geoffroyi in Myers et al. (2002), updated in Wozencraft (2005). SSP: braccatus (Wozencraft 2005 and do Nasimento 2016).

X TXNM: as Oncifelis geoffroyi in Myers et al. (2002), updated in Wozencraft (2005). SSP: paraguae (do Nascimento 2014).

X TXNM: as L. tigrinus in Myers et al. (2002), updated by Trigo et al. (2013). DIST: E PY in Myers et al. (2002). Johnson et al. (1999) and Trigo et al. (2008) report it from W PY, but the information presented is confusing as to the origin of their samples. No clear evidence from W PY is available.

X SSP: mitis, Murray and Gardner (1997).

SSP: P. c. cabrerae and P. c. capricorniensis occur in PY, but geographic limits are uncertain (Culver et al. 2000).

X SSP: eyra, de Oliveira (1998). TXNM: as Herpailurus yagouaroundi in Myers et al. (2002), updated in Wozencraft (2005). 


\section{Family Canidae}

Cerdocyon thous (Linnaeus, 1766)

Chrysocyon brachyurus (Illiger, 1815)

Lycalopex gymnocercus (G. Fischer, 1814)

Speothos venaticus (Lund, 1842)

\section{Family Mustelidae}

\section{Subfamily Lutrinae}

Lontra longicaudis (Olfers, 1818)

Pteronura brasiliensis (Gmelin, 1788)

\section{Subfamily Mustelinae}

Eira barbara (Linnaeus, 1758)

Galictis cuja (Molina, 1782)

Galictis vittata (Schreber, 1776)

\section{Family Mephitidae}

Conepatus chinga (Molina, 1782)

Nasua nasua (Linnaeus, 1766)

Procyon cancrivorus (Cuvier, 1798)

\section{Order Perissodactyla}

Family Tapiridae

Tapirus terrestris (Linnaeus, 1758)

\section{Order Cetartiodactyla}

\section{Family Tayassuidae}

Parachoerus wagneri (Rusconi, 1930)

Pecari tajacu (Linneus 1758)

Tayassu pecari (Link, 1795)

\section{Family Camelidae}

Lama guanicoe (Müller, 1776)

\section{Family Cervidae}

Blastocerus dichotomus (Illiger, 1815)

Mazama sp. (Erxleben, 1777)

Mazama gouazoubira (G. Fischer von Waldheim, 1814)

Mazama nana (Hensel, 1872)

Ozotoceros bezoarticus (Linnaeus, 1758)

\section{Orden Rodentia}

\section{Suborder Sciuromorpha}

Family Sciuridae

Hadrosciurus spadiceus (Olfers, 1818)

Hadrosciurus sp.

Sciurus ignitus (Gray, 1867)

\section{Family Procyonidae}

SSP: entrerianus, Berta (1982).

$\mathrm{X}$

X TXNM: as Pseudalopex gymnocercus in Myers et al. (2002), updated in Wozencraft (2005). SSP: gymnocercus, Wozencraft (2005).

X DIST: reported by Myers et al. (2002) for E PY, but Beisiegel and Zuercher (2005) extend the distribution to NW PY.

SSP: wingei, documented from SE PY (Beisiegel and Zuercher, 2005), another subspecies probably occurring in $\mathrm{PY}$ is venaticus, but no records are available (Beisiegel and Zuercher, 2005).

X SSP: platensis, Feijó and Langguth (2013)

X SSP:paranensis, Pickles et al. (2011).

X SSP: barbara, Presley (2000).

X TXNM: as Galictis cuja in Myers et al. (2002), which at that time included both G. cuja and G. vittata. Taxonomy previously unstable but both are now recognized as separate taxa (Bornholdt et al. 2013).

DIST: W and E PY (Bornholdt et al. 2013)

X NSRC: Bornholdt et al. (2013) reported it for eastern PY. TXNM: as Galictis cuja (part) in Myers et al. (2002), see above.

X DIST: Myers et al. (2002) reported it from W PY, recently recorded from E PY Velázquez and Ramírez Pinto (2014).

X SSP: spadicea, Gompper and Decker (1998), Wozencraft (2005).

X SSP: nigripes, Wozencraft (2005) Sul, and potentially in the Paraguayan Chaco (Groves and Grubb 2011), and a revision is needed.
TXNM: as Catagonus in Myers et al. (2002), updated by Dutra et al. (2016).

X TXNM: as Tayassu tajacu in Myers et al. (2002). Groves and Grubb (2011) suggested more than one taxon may exist in PY populations.

X SSP: albirostris, the name T. p. pecari (Link 1795), formerly applied to PY populations, was restricted by Hershkovitz (1963) to Cayenne, French Guiana (Groves and Grubb 2011).

SSP: cacsilensis, Groves and Grubb (2011).

$\mathrm{X}$

$\mathrm{X}$

TXNM: the name M. americana was restricted by Groves and Grubb (2011) to northern South America. PY populations may be ascribed to M. rufa or M. jucunda, pending revision.

$\mathrm{X}$

TXNM: as M. gouazoupira in Myers et al. (2002).

X SSP: leucogaster, Jackson (1987). SSP: tajacu Groves and Grubb (2011).

NSRC: as Sciurus urucumus by D'Elía et al. (2008a). SSP: spadiceus, de Vivo and Carmignotto (2015).

NSRC: specimen of unidentified species reported by D'Elía et al. (2008a) from the Chaco, along PY River.

X X NSRC: Timm et al. (2015). 


\section{Subfamily Sigmodontinae}

Akodon azarae (Fischer, 1829)

Akodon montensis Thomas, 1913

Akodon paranaensis Christoff et al. 2000

Akodon toba Thomas, 1921

Andalgalomys pearsoni (Myers, 1977)

Bibimys chacoensis (Shamel, 1931)

Calomys callosus (Rengger, 1830)

Calomys laucha (Fischer, 1814)

Calomys musculinus (Thomas, 1913)

Calomys tener (Winge, 1887)

Cerradomys maracajuensis (Langguth and Bonvicino, 2002)

Cerradomys scotti (Langguth and Bonvicino, 2002)

Euryoryzomys russatus (Wagner, 1848)

Graomys chacoensis (J. A. Allen, 1901)

Holochilus vulpinus (Brants, 1827)

Holochilus chacarius Thomas, 1906

Hylaeamys megacephalus (G. Fischer, 1814)

Juliomys pictipes (Osgood, 1933)

Necromys lasiurus (Lund, 1840)

Necromys lenguarum (Thomas, 1898)

Nectomys rattus (Pelzeln, 1883)

Oecomys cf. mamorae (Thomas, 1906)

Oecomys franciscorum (Pardiñas et al. 2016)

Oligoryzomys chacoensis (Myers and Carleton, 1981)

Oligoryzomys flavescens (Waterhouse 1837)

Oligoryzomys mattogrossae (J. A. Allen, 1916)

Oligoryzomys nigripes (Olfers, 1818)

Oxymycterus delator Thomas, 1903

Oxymycterus quaestor Thomas, 1903

Pseudoryzomys simplex (Winge, 1887)

Rhipidomys macrurus (Gervais, 1855)

Scapteromys aquaticus Thomas, 1920

Sooretamys angouya (Fischer, 1814)

Thaptomys nigrita (Lichtenstein, 1829) $x$

$x$

\section{Family Erethizontidae}

\section{Subfamily Erethizontinae}

Coendou prehensilis (Linnaeus, 1758)

Coendou spinosus (F. Cuvier, 1823)

SSP: bibianae, Pardiñas et al. (2015).

X TXNM: as A. cursor in Myers et al. (2002), updated by Pardiñas et al. (2015).

X NSRC: D'Elía et al. (2008).

SPP: pearsoni, Braun (2015).

DIST: Myers et al. (2002) reports it for W PY, Salazar-Bravo (2015) reports it from E PY, but likely based on specimens of C. tener (González-Ittig et al. 2014).

X DIST: reported for E PY by Myers et al. (2002); Salazar-Bravo (2015) reported specimens from W PY.

X NSRC: de la Sancha (2014), González-Ittig et al. (2014).

X TXNM: as Oryzomys buccinatus (in part) in Myers et al. (2002), updated by Percequillo et al. (2008).

X NSRC: Percequillo et al. (2008).

TXNM: as Oryzomys buccinatus (in part) in Myers et al. (2002); updated by Percequillo et al. (2008).

X TXNM: as Oryzomys intermedius in Myers et al. (2002); updated by Percequillo (2015).

X TXNM: as G. griseoflavus in Myers et al. (2002); updated by Braun and Patton (2015).

X TXNM: as H. brasiliensis (in part) in Myers et al. (2002), updated by D'Elía et al. (2015). DIST: restricted to E PY in D'Elía et al. (2015).

X DIST: E and W PY (D'Elía et al. 2015). SSP: chacarius, Gonçalves et al. (2015).

X TXNM: as Oryzomys capito in Myers et al. (2002), updated by Weksler et al. (2006).

X NSRC: de la Sancha et al. (2009).

X TXNM: as Bolomys lasiurus (part) in Myers et al. (2002), updated by D'Elía et al. (2008b).

NSRC: by D'Elía et al. (2008b).

TXNM: as Bolomys lasiurus (part) in Myers et al. (2002), updated by D'Elía et al. (2008b).

X TXNM: as N. squamipes in Myers et al. (2002), updated by Bonvicino and Weksler (2015). TXNM: as O. mamorae (part) in Myers et al. (2002).

X NSRC: Newly described by Pardiñas et al. (2016). TXNM: as O. mamorae (part) in Myers et al. (2002). Described by Pardiñas et al. (2016). DIST: reported for E and W PY by Myers et al. (2002). restricted to W PY by Weksler and Bonvicino (2005).

NSRC: Weksler and Bonvincino (2005) TXNM: as O. microtis in Myers et al. (2002), updated by Weksler and Bonvicino (2005).

TXNM: as O. microtis (part) in Myers et al. (2002), restricted to E PY by Weksler and Bonvicino (2015).

NSRC: as O. misionalis by D'Elía et al. (2008a). TXNM: updated to O. quaestor by de Oliveira and Gonçalves (2015).

X TXNM: as Sphiggurus spinosus in Myers et al. (2002), updated by Voss (2015). 


\section{Family Chinchillidae}

Lagostomus maximus (Desmarest,1817)

Family Caviidae

Subfamily Caviinae

Cavia aperea Erxelben, 1777

Galea leucoblephara (Burmeister, 1861)

Subfamily Dolichotinae

Dolichotis salinicola Burmeister, 1876

Subfamily Hydrochoerinae

Hydrochoerus hydrochaeris (Linnaeus, 1766)

Family Dasyproctidae

Dasyprocta azarae Lichtenstein,1823

Family Cuniculidae

Cuniculus paca (Linnaeus, 1766)

Family Ctenomyidae

Ctenomys conoveri Osgood, 1946

Ctenomys dorsalis Thomas, 1900

Ctenomys paraguayensis Contreras, 2000

Ctenomys pilarensis Contreras, 1993

Family Echimyidae

Subamily Dactylomyinae

Kannabateomys amblyonyx (Wagner, 1845)

Subamily Eumysopinae

Clyomys laticeps (Thomas, 1909)

Euryzygomatomys spinosus (G. Fischer, 1814)

Proechimys longicaudatus (Rengger, 1830)

Thrichomys fosteri Thomas, 1903

Family Myocastoridae $x$

$\mathrm{X}$

$\mathrm{X}$ TXNM: validity of name questioned by Bidau (2015). However, because the publication probably does not follow rules of the International Code of Zoological Nomenclature (ICZN, 2012), what is questionable is the availability (not the validity) of the name.
SSP: hypoleuca, Dunnum (2015).

TXNM: as Galea musteloides in Myers et al. 2002, updated by Dunnum and Salazar-Bravo (2010).

SSP: demissa, Dunnum (2015)

TXNM: as Hydrochaeris hydrochaeris in Myers et al. (2002), updated by Dunnum (2015).

DIST: in both regions in Myers et al. 2002; Patton and Emmons (2015) placed it in E and W PY, but no records were found for the $\mathrm{W}$.

TXNM: as Agouti paca in Myers et al. (2002), updated by Patton (2015).
SSP: immolis, Spotorno and Patton (2015).
We conclude that the current status of knowledge on Paraguayan mammals is incomplete and offers a fertile ground for young scientists, offering many valuable and interesting taxonomic, biogeographic, and ecologic questions yet to be resolved.

\section{Acknowledgments}

We thank Robert Owen and two anonymous reviewers whose comments and suggestions greatly improved an earlier version of this contribution.

\section{Literature Cited}

Agnarsson, I., and L. J. May-Collado. 2008. The phylogeny of Cetartiodactyla: the importance of dense taxon sampling, missing data, and the remarkable promise of cytochrome $\mathrm{b}$ to provide reliable species-level phylogenies. Molecular Phylogenetics and Evolution 48:964-985.

Andelman, S. J., AND M. R. Willig. 2002. Alternative conservation reserve configurations for Paraguayan bats: Considerations of spatial scale. Conservation Biology 16:1352-1363.
Aristide, L., I. M. Soto, M. D. Mudry, AND M. Nieves. 2014. Intra and interspecific variation in cranial morphology on the southernmost distributed Cebus (Platyrrhini, Primates) species. Journal of Mammalian Evolution 21:349-355.

AZARA, F. DE. 1801. Essais sur l'histoire naturelle des quadrupédes de la province du Paraguay. Charles Pougens. Paris, France.

AzARA, F. DE. 1802. Apuntamientos para la historia natural de los quadrúpedos del Paraguay y Río de la Plata. Imprenta de la Viuda de Ibarra. Madrid, Spain.

Barquez, R. M. 2006. Orden Chiroptera. Pp. 56-86 in Mamíferos de Argentina sistemática y distribución (Barquez, R. M., M. M. Díaz, and R. A. Ojeda, eds.). Asociación Argentina para el Estudio de los Mamíferos. Tucumán, Argentina.

BARTRINA, L. 2007. Contexto geográfico general. Pp. 25-32 in Biodiversidad del Paraguay: Una aproximación a sus realidades (Salas-Dueñas, D. A., and J. F. Facetti, eds.). Fundación Moisés Bertoni. Asunción, Paraguay.

BeIsiegel, B. M., AND G. L. Zuercher. 2005. Speothos venaticus. Mammalian Species 783:1-6.

Benirschke, K., A. T. Kumamoto, and D. A. Meritt. 1985. Chromosomes of the Chacoan peccary, Catagonus wagneri (Rusconi). Journal of Heredity 76:95-98. 
BenIRSCHKE, K., R. J. Low, AND M. ByRd. 1989a. Further observations on the causes of death in the Chacoan peccary, Catagonus wagneri. Verhandlungsbericht des Internationalen Symposiums über die Erkrankungen der Zoo- und Wildtiere 31:7 1-78.

BeniRsChke, K., M. L. Byrd, And R. J. Lowe. 1989b. The Chaco region of Paraguay: peccaries and Mennonites. Interdisciplinary Science Reviews 14:144-147.

Berta, A. 1982. Cerdocyon thous. Mammalian Species 186:1-4. Bertoni, A. W. 1939. Catálogos sistemáticos de los vertebrados del Paraguay. Revista de la Sociedad Científica del Paraguay 4:1-49.

BidAu, C. J. 2015. Family Ctenomyidae Lesson, 1842. Pp. 818-877 in Mammals of South America, Volume 2, Rodents (Patton, J. L., U. F. J. Pardiñas, and G. D'Elía. eds.). The University of Chicago Press. Chicago, U. S. A.

Bonvicino, C. R., And M. Weksler. 2015. Genus Nectomys Peters, 1861. Pp. 369-376 in Mammals of South America, Volume 2, Rodents (Patton, J. L., U. F. J. Pardiñas and G. D'Elía. eds.). The University of Chicago Press. Chicago, U.S. A.

Bonvicino, C. R., A. N. Menezes, A. Lazar, V. Penna-Firme, C. Bueno, M. C. Viana, P. S. D'Andrea, And A. Langguth. 2015. Chromosomes and phylogeography of Sylvilagus (Mammalia, Leporidae) from Eastern Brazil. Oecologia Australis 19:158-172.

Bornholdt, R., K. Helgen, K. P. Koepfli, L. Oliveira, M. Lucherini, And E. EIZIRIK. 2013. Taxonomic revision of the genus Galictis (Carnivora: Mustelidae): species delimitation, morphological diagnosis, and refined mapping of geographical distribution. Zoological Journal of the Linnean Society 167:449-472.

BoYLE, S. A. 2014. Pitheciids in fragmented habitats: Land cover change and its implications for conservation. American Journal of Primatology 78:534-549.

Braun, J. K. 2015. Genus Andalgalomys D. F. Williams and Mares, 1978. Pp. 469-471 in Mammals of South America, Volume 2, Rodents (Patton, J. L., U. F. J. Pardiñas and G. D'Elía. eds.). The University of Chicago Press. Chicago, U. S. A.

Braun, J. K., and J. L. Patton. 2015. Genus Graomys Thomas, 1916. Pp. 523-531 in Mammals of South America, Volume 2, Rodents (Patton, J. L., U. F. J. Pardiñas and G. D'Elía. eds.). The University of Chicago Press. Chicago, U. S. A.

BRoOKS, D. M. 1992. Reproductive behaviour and development of the young of the chacoan peccary (Catagonus wagneri Rusconi, 1930), in the Paraguayan Chaco. Zeitschrift für Säugetierkunde 57:316-317.

Brooks, D. M., R. E. Bodmer, and S. Matola (eds.). 1997. Tapirs Status Survey and Conservation Action Plan. IUCN/SSC Tapir Specialist Group. IUCN. Gland, Switzerland.

Byrd, M. L., K. B. BenirschKe, And G. C. Gould. 1988. Establishment of the first captive colony of the Chaco peccary, Catagonus wagneri. Zoologische Garten 58:265-274.

Byrne, H., A. B. Rylands, J. C. Carneiro, J. W. Lynch Alfaro, F. Bertuol, M. N. F. da Silva, M. Messias, C. P. Groves, R. A. Mittermeier, I. Farias, T. Hrbek, H. Schneider, I. Sampaio, and J. P. Boubli. 2016. Phylogenetic relationships of the New World titi monkeys (Callicebus): first appraisal of taxonomy based on molecular evidence. Frontiers in Zoology 13:1-25.

Campos, J. M., D. A. Meritt, And I. Benitez. 2004. On the occurrence of the owl monkey (Aotus azarae) in Cerro León, Chaco, Paraguay. Neotropical Primates 12:63-64.
Carleton, M. D., and G. G. Musser. 2005. Order Rodentia. Pp. 745-752 in Mammal Species of the World, third Edition (Wilson, D. E., and D. M. Reeder, eds.). The Johns Hopkins University Press. Baltimore, U. S. A.

CARTES, J. L., J. Thompson, And A. Yanosky. 2015. El Chaco Paraguayo como uno de los últimos refugios para los mamíferos amenazados del Cono Sur. Paraquaria Natural 3:37-47.

Casado, F., C. R. Bonvicino, C. Nagle, B. Comas, T. D. Manzur, M. M. Lahoz, and H. N. SeuÁnez. 2010. Mitochondrial divergence between 2 populations of the hooded capuchin, Cebus (Sapajus) cay (Platyrrhini, Primates). Journal of Heredity 101:261-269.

Cerqueira, R., and C. J. Tribe. 2008. Genus Didelphis Illiger, 1811. Pp. 17-25 in Mammals of South America Volume 1: Marsupials, xenarthans, shrews and bats (Gardner, A. L., ed.). The University of Chicago Press. Chicago, U. S. A.

Chemisquy, M., AND D. Flores. 2012. Taxonomy of the southernmost populations of Philander (Didelphimorphia, Didelphidae), with implications for the systematics of the genus. Zootaxa 3481:60-72.

Chu, Y. K., R. D. Owen, L. M. González, and C. B. Jonsson. 2003. The complex ecology of hantavirus in Paraguay. American Journal of Tropical Medicine and Hygiene 69:263-268.

Chu, Y. K., B. Milligan, R. D. Owen, D. G. Goodin, and C. B. Jonsson. 2006. Phylogenetic and geographical relationships of hantavirus strains in eastern and western Paraguay. American Journal of Tropical Medicine and Hygiene 75:1127-1134.

Chu, Y. K., D. G. Goodin, R. D. Owen, D. KoCH, AND C. B. Jonsson. 2009. Sympatry of two Hantavirus strains, Paraguay, 2003-2007. Emerging Infectious Diseases 15:1977-1980.

ContRERAS, J. R. 1993. Una nueva especie de roedor excavador del género Ctenomys procedente del Paraguay Oriental (Rodentia, Octodontinae, Ctenomyinae), descripción preliminar. Resúmenes VI Congreso Iberoamericano de Conservación y Zoología de Vertebrados (Santa Cruz, Bolivia) 44-46.

Contreras, J. R. 2000. Ctenomys paraguayensis, una nueva especie de roedor excavador procedente del Paraguay Oriental (Mammalia, Rodentia, Ctenomyidae). Revista del Museo Argentino de Ciencias Naturales, nueva serie 2:61-68. Culver, M., W. E. Johnson, J. Pecon-Slattery, and S. J. O'brien. 2000. Genomic ancestry of the American puma (Puma concolor). Journal of Heredity 91:186-197.

D'ElíA, G., AND U. F. J. PARDIÑAS. 2004. Systematics of Argentinean, Paraguayan, and Uruguayan swamp rats of the genus Scapteromys (Rodentia, Cricetidae, Sigmodontinae). Journal of Mammalogy 85:897-910.

D'ElíA, G., ANd P. Myers. 2014. On Paraguayan Thrichomys (Hystricognathi: Echimyidae): the distinctiveness of Thrichomys fosteri Thomas, 1903. Therya 51:153-166.

D'Elía, G., I. Mora, P. Myers, and R. D. Owen. 2008a. New and noteworthy records of Rodentia (Erethizontidae, Sciuridae, and Cricetidae) from Paraguay. Zootaxa 1784:39-57.

D’Elía, G., U. F. J. Pardiñas, J. P. Jayat, and J. Salazar-Bravo. 2008b. Systematics of Necromys (Rodentia, Cricetidae, Sigmodontinae): Species limits and groups, with comments on historical biogeography. Journal of Mammalogy 89:778-790. D’Elía, G., J. D. Hanson, M. R. Mauldin, P. Teta, and U. F. J. Pardiñas. 2015. Molecular systematics of South American marsh rats of the Genus Holochilus (Muroidea, Cricetidae, Sigmodontinae). Journal of Mammalogy 96:1081-1094. 
Davis, W. B., And A. L. Gardner. 2008. Genus Eptesicus. Pp. 440450 in Mammals of South America Volume 1: Marsupials, xenarthans, shrews and bats (Gardner, A. L., ed.). The University of Chicago Press. Chicago U. S. A.

de Angelo, C., A. Paviolo, and M. Di Bitetti. 2011a. Differential impact of landscape transformation on pumas (Puma concolor) and jaguars (Panthera onca) in the Upper Paraná Atlantic Forest. Diversity and Distributions 17:422-436.

de Angelo, C., A. Paviolo, D. Rode, L. Cullen. 2011b. Participatory networks for large-scale monitoring of large carnivores: pumas and jaguars of the Upper Paraná Atlantic Forest. Oryx 45:534-545. DE LA SANCHA, N. U. 2014. Patterns of small mammal diversity in fragments of subtropical interior Atlantic Forest in eastern Paraguay. Mammalia 78:437-449.

de la Sancha, N. U., and G. D'ElíA. 2015. Additions to the Paraguayan mammal fauna: the first records of two marsupials (Didelphimorphia, Didelphidae) with comments on the alpha taxonomy of Cryptonanus and Philander. Mammalia 79:343-356.

de la Sancha, N. U., S. Solari, and R. D. Owen. 2007. First records of Monodelphis kunsi Pine (Didelphimorphia, Didelphidae) from Paraguay, with an evaluation of its distribution. Mastozoologia Neotropical 14:241-247.

de la Sancha, N. U., G. D’Elía, F. Netto, P. Perez, and J. Salazar-bravo. 2009. Discovery of Juliomys (Rodentia, Sigmodontinae) in Paraguay, a new genus of Sigmodontinae for the country's Atlantic Forest. Mammalia 73:162-167.

de la Sancha, N. U., G. D’Elía, C. J. Tribe, P. E. Pérez, L. Valdez, and R. H. PINE. 2011. Rhipidomys (Rodentia, Cricetidae) from Paraguay: noteworthy new records and identity of the Paraguayan species. Mammalia 75:269-276.

de la Sancha, N. U., G. D’Elía, and P. Teta. 2012. Systematics of the subgenus of mouse opossums Marmosa (Micoureus) (Didelphimorphia, Didelphidae) with noteworthy records from Paraguay. Mammalian Biology-Zeitschrift für Säugetierkunde 77:229-236.

de la Sancha, N. U., C. L. Higgins, S. J. Presley, and R. E. Strauss. 2014. Metacommunity structure in a highly fragmented forest: has deforestation in the Atlantic Forest altered historic biogeographic patterns? Diversity and Distributions 20:1058-1070.

de Oliveira, J. A., And P. R. Gonçalves. 2015. Genus Oxymycterus Waterhouse, 1837. Pp. 247-268 in Mammals of South America, Volume 2, Rodents (Patton, J. L., U. F. J. Pardiñas and G. D’Elía. eds.). The University of Chicago Press. Chicago, U. S. A.

de OliveirA, T. G. 1998. Herpailurus yaguaroundi. Mammalian Species 578:1-6.

de Vivo, M., and A. P. Carmignotto. 2015. Family Sciuridae G. Fischer, 1817. Pp. 1-48 in Mammals of South America, Volume 2, Rodents (Patton, J. L., U. F. J. Pardiñas and G. D’Elía, eds.). The University of Chicago Press. Chicago, U. S. A.

Díaz, L. A., M. P. Díaz, W. R. Almirón, and M. S. Contigiani. 2007. Infection by UNA virus (Alphavirus; Togaviridae) and risk factor analysis in black howler monkeys (Alouatta caraya) from Paraguay and Argentina. Transactions of the Royal Society of Tropical Medicine and Hygiene 101:1039-1041.

Dick, C. W., And D. D. Gettinger. 2005. A faunal survey of Streblid flies (Diptera: Streblidae) associated with bats in Paraguay. Journal of Parasitology 91:1015-1024.
DO NASCIMENTO, F. 2014. On the morphological variation and taxonomy of the Geoffroy's cat Leopardus geoffroyi (d'Orbigny\& Gervais, 1844) (Carnivora, Felidae). Papéis Avulsos de Zoologia: Museu de Zoologia da Universidade de Sao Paulo 54:129-160.

do Nascimento, F., and P. dos Santos Pompeu, and M. Passamani. 2016. Range extension of the pantanal cat Leopardus braccatus (Carnivora, Felidae) in a Cerrado-Caatinga-Atlantic Forest ecotone, Brazil. Mastozoología Neotropical, 23:171-177.

Dunnum, J. L. 2015. Family Caviidae G. Fischer, 1817. Pp. 690-726 in Mammals of South America, Volume 2, Rodents (Patton, J. L., U. F. J. Pardiñas and G. D’Elía. eds.). The University of Chicago Press. Chicago, U. S. A.

Dunnum, J. L. And J. Salazar-Bravo. 2010. Phylogeny, evolution, and systematics of the Galea musteloides complex (Rodentia: Caviidae). Journal of Mammalogy 91:243-259.

Durette-Dusset, M. C., AND C. Vaucher. 1999. Molostrongylus mbopi n. sp. (Nematoda: Trichostrongylina, Molinewidea) parasite of three Molossops species (Chiroptera, Molossidae) from Paraguay. Revue Suisse de Zoologie 106:407-418.

Dutra, R. P., D. M. Casali, R. V. Missagia, G. M. Gasparini, F. A. Perinl, And M. A. Cozzuol. 2016. Phylogenetic Systematics of Peccaries (Tayassuidae: Artiodactyla) and a Classification of South American Tayassuids. Journal of Mammalian Evolution DOI 10.1007/s10914-016-9347-8.

Eger, J. L. 2008. Family Molossidae. Pp. 399-439 in Mammals of South America Volume 1, Marsupials, xenarthans, shrews and bats (Gardner, A. L., ed.). The University of Chicago Press. Chicago U. S. A.

Emmons, L. H., J. L. Patton, And Y. L. R. Leite. 2015. Subfamily Dactylomyinae Tate, 1935. Pp. 880-888 in Mammals of South America, Volume 2, Rodents (Patton, J. L., U. F. J. Pardiñas and G. D'Elía. eds.). The University of Chicago Press. Chicago, U. S. A.

FARIÑA, T. 1973. The climate of Paraguay. Pp. 33-38 in Paraguay: Ecological Essays (Gorham, J. R., ed.). Academy of Arts and Sciences of the Americas. Miami, U. S. A.

Feijó, A., And A. Langguth. 2013. Mamíferos de médio e grande porte do Nordeste do Brasil: Distribuição e taxonomia, com descrição de novas espécies. Revista Nordestina de Biologia 22:3-225.

Frutos, S. D., and R. A. van den Bussche. 2002. Genetic diversity and gene flow in nine-banded armadillos in Paraguay. Journal of Mammalogy 83:815-823.

Gamarra de Fox, I., And A. Martin. 1996. Mastozoología. Pp. 469573 in Colecciones de flora y fauna del Museo de Historia Natural del Paraguay (Romero Martínez, O., ed.). Museo Nacional de Historia Natural del Paraguay, Dirección de Parques Nacionales y Vida Silvestre, Ministerio de Agricultura y Ganadería, Asunción, Paraguay.

Garbino, G. S. T. and A. TeJedor. 2013. Natalus macrourus (Gervais, 1856) (Chiroptera: Natalidae) is a senior synonym of Natalus espiritosantensis (Ruschi, 1951). Mammalia 77: 237-240.

Gardner, A. L. (ED.). 2008a. Mammals of South America Volume 1: Marsupials, xenarthans, shrews and bats. The University of Chicago Press. Chicago, U. S. A.

Gardner, A. L. 2008b. Order Pilosa Flower, 1883. Pp. 157177 in Mammals of South America Volume 1, Marsupials, xenarthans, shrews and bats (Gardner, A. L., ed.). The University of Chicago Press. Chicago U. S. A. 
Gardner, A. L. 2008c. Genus Caluromys J. A. Allen, 1900. Pp. 3-11 in Mammals of South America Volume 1, Marsupials, xenarthans, shrews and bats (Gardner, A. L., ed.). The University of Chicago Press. Chicago U. S. A.

Gardner, A. L. 2008d. Tribe Stenodermatini P. Gervais, 1856. Pp. 357-363 11 in Mammals of South America Volume 1, Marsupials, xenarthans, shrews and bats (Gardner, A. L., ed.). The University of Chicago Press. Chicago U. S. A.

Gardner, A. L. 2008e. Tribe Sturnirini. Pp. 363-376 in Mammals of South America Volume 1, Marsupials, xenarthans, shrews and bats (Gardner, A. L., ed.). The University of Chicago Press. Chicago U. S. A.

Gardner, A. L. 2008f. Family Noctilionidae Gray 1821. Pp. 384389 in Mammals of South America Volume 1, Marsupials, xenarthans, shrews and bats (Gardner, A. L., ed.). The University of Chicago Press. Chicago U. S. A.

Gardner, A. L., And M. D'agosto. 2008. Metachirus Burmeister, 1854. Pp. 35-39 in Mammals of South America Volume 1, Marsupials, xenarthans, shrews and bats (Gardner, A. L., ed.). The University of Chicago Press. Chicago U. S. A.

Gardner, A. L., ANd C. O. Handley JR. 2008. Genus Lasiurus Gray 1831. Pp. 457-468 in Mammals of South America Volume 1, Marsupials, xenarthans, shrews and bats (Gardner, A. L., ed.). The University of Chicago Press. Chicago U. S. A.

Gibb, G.C., F. L. Condamine, M. Kuch, J. Enk, N. Moraes-Barros, M. Superina, H.N. Poinar, AND F. Delsuc. 2016. shotgun mitogenomics provides a reference phylogenetic framework and timescale for living xenarthrans. Molecular Biology and Evolution 33:621-642.

Giordano, A. J., AND W. B. Ballard. 2010. Noteworthy record of a black howler monkey (Alouatta caraya) from the central dry Chaco of Paraguay. Neotropical Primates 17:74-75.

Giordano, A. J., N. Mujica, F. Ramírez, And C. K. Nielsen. 2014. Jaguar (Panthera onca) records from the south central Paraguayan Chaco: Implications for transboundary surveys at the southern range edge. Cat News 60:38-40.

Gompper, M. E., AND D. M. DeCKer. 1998. Nasua nasua. Mammalian Species 580:1-9.

Gonçalves P. R., P. Teta, and C. Bonvicino C. 2015. Genus Holochilus Brandt, 1835. Pp. 325-335 in Mammals of South America, 2. Rodents (Patton, J. L., U. F. J. Pardiñas, and G. D’Elía, eds.). University of Chicago Press. Chicago, U. S. A.

González-Ittig, R. E., N. Kandel, S. Levis, G. Calderón, J. SalazarBravo, and C. N. Gardenal. 2014. Molecular Systematics of the South American rodent Calomys laucha (Cricetidae: Sigmodontinae), a reservoir of the Laguna Negra hantavirus. Canadian Journal of Zoology 92:1093-1098.

Goodin, D. G., D. E. Koch, R. D. Owen, Y. K. Chu, J. M. S. Hutchinson, AND C. B. Jonsson. 2006. Land cover associated with hantavirus presence in Paraguay. Global Ecology and Biogeography 15:519-527.

Goodin, D. G., R. Paige, R. D. Owen, K. Ghimire, D. E. Koch, Y. K. Chu, AND C. B. Jonsson. 2009. Microhabitat characteristics of Akodon montensis, a vector for hantavirus, and hantaviral seroprevalence in an Atlantic Forest site in Eastern Paraguay. Journal of Vector Ecology 34:104-113.

Gorham, J. R. 1973. Paraguay: Ecological Essays. Academy of Arts and Sciences of the Americas. Miami, U. S. A.
GorResen, P. M., AND M. R. Willig. 2004. Landscape responses of bats to habitat fragmentation in Atlantic forest of Paraguay. Journal of Mammalogy 85:688-697.

Gorresen, P. M., M. R. Willig, and R. E. Strauss. 2005. Multivariate analysis of scale-dependent associations between bats and landscape structure. Ecological Applications 15:2126-2136.

Graciollı, G., C. W. Dick, And D. D. Gettinger. 2006. A faunal survey of Nycteribiid flies (Diptera: Nycteridiidae) associated with bats of Paraguay. Zootaxa 1220:35-46.

Griffiths, T. A., And A. L. Gardner. 2008. Glossophaginae. Pp. 224-244 in Mammals of South America Volume 1, Marsupials, xenarthans, shrews and bats (Gardner, A. L., ed.). The University of Chicago Press. Chicago U. S. A.

Groves, C. 2005. Order Primates. Pp.111-184 in Mammal Species of the World: A Taxonomic and Geographic Reference, 3rd ed. (Wilson, D. E., and D. M. Reeder eds.). Johns Hopkins University Press. Baltimore, U. S. A.

Groves, C. And P. GrubB. 2011. Ungulate Taxonomy. The John Hopkins University Press. Baltimore, U. S. A.

GruBB, P. 2005. Artiodactyla. Pp. 637-722 in Mammal Species of the World: A Taxonomic and Geographic Reference, 3rd ed. (Wilson, D. E., and D. M. Reeder eds.). Johns Hopkins University Press. Baltimore, U. S. A.

Handen, C. E., And K. Benirschke. 1991. Giant chacoan peccary: Feeding and social behavior of a captive group in natural habitat. Zoo Biology 10:209-217.

Handen C. E., J. Unger, And D. Meritt. 1994. Current status of the Tagua (Catagonus wagneri) in Paraguay. Zoologishe Garten 64:329-337.

HAYES, F. E. 1995. Status, distribution, and biogeography of the birds of Paraguay. Monographs in Field Ornithology $1: 1-230$.

Heddergott, M. 2008. Two new species of Parichoronyssus Radovsky, 1966 (Acari, Dermanyssoidea, Macronyssidae) from bats of the Genus Phyllostomus (Mammalia, Chiroptera, Phyllostomidae) in Paraguay and Cuba. Spixiana 31:183193.

Hershkovitz, P. 1963. The nomenclature of South American peccaries. Proceedings of the Biological Society of Washington 76:85-87.

HILL, K., AND J. PAdWE. 2000. Sustainability of Aché hunting in the Mbaracayú Reserve, Paraguay. Pp.79-105 in Hunting for sustainability in tropical forests (Robinson, J. G., and E. I. Bennett, eds.). Columbia University Press. New York, U. S. A. Hill, K., J. Padwe, C. Bejyvagl, A. Bepurangl, F. Jakugl, R. Tykuarangl, and T. TYKUARANGI. 1997. Impact of hunting on large vertebrates in the Mbaracayú Reserve, Paraguay. Conservation Biology 11:1339-1353.

Hill, K., G. McMillan, and R. Fariña. 2003. Hunting-related changes in game encounter rates from 1994 to 2001 in the Mbaracayú reserve, Paraguay. Conservation Biology 17:1312-1323.

Hoyos, M., P. Bloor, T. Defler, J. Vermeer, F. Rohe, and I. Farias. 2016. Phylogenetic relationships within the Callicebus cupreus species group (Pitheciidae: Primates): Biogeographic and taxonomic implications. Molecular Phylogenetics and Evolution 102:208-219.

Hurtado, N., And V. Pacheco. 2014. Phylogenetic analysis of the genus Mimon Gray, 1847 (Mammalia, Chiroptera, 
Phyllostomidae) with description of a new genus. Therya 5:751-791.

InTERnATIONAL Commission on Zoological Nomenclature (ICZN). 2012. International Code of Zoological Nomenclature, online version http://www.iczn.org.

JACKSON, J. E. 1987. Ozotoceros bezoarticus. Mammalian Species 295:1-5.

Johnson, W. E., J. P. Slattery, E. Eizirik, J. H. Kim, M. M. Raymond, C. Bonacic, R. Cambre, P. Crawshaw, A. Nunes, H. N. Seuánez, M. A. M. Moreira, K. L. Seymour, F. Simon, W. Swanson, S. J. O’Brien. 1999. Disparate phylogeographic patterns of molecular genetic variation in four closely related South American small cat species. Molecular Ecology 8:S79-S94.

Kwon, M., And A. L. Gardner. 2008. Desmodontinae. Pp. 218214 in Mammals of South America Volume 1, Marsupials, xenarthans, shrews and bats (Gardner, A. L., ed.). The University of Chicago Press. Chicago U. S. A.

LARSON, S. E. 1997. Taxonomic re-evaluation of the Jaguar. Zoo Biology 16:107-120.

LÓPEZ-GONZÁLEZ, C. 2004. Ecological zoogeography of the bats of Paraguay. Journal of Biogeography 31:33-45.

LóPez-GonzÁlez, C. 2005. Murciélagos del Paraguay. Biosfera, Publicaciones del Comité Español del Programa MaB y de la Red IberoMaB de la UNESCO. Sevilla, Spain.

López-González, C., ANd S. J. Presley. 2001. Taxonomic status of Molossus bondae J. A. Allen, 1904 (Chiroptera: Molossidae), with description of a new subspecies. Journal of Mammalogy 82:760-774.

López-González, C., S. J. Presley, R. D. Owen, M. R. Willig, and I. GAMARRA DE Fox. 1998. Noteworthy records of bats (Chiroptera) from Paraguay. Mastozoología Neotropical 4:5-9.

López-gonzález, C., P. Myers, N. de la Sancha, G. D’Elía, and L. VAldez. 2014. Historia de la mastozoología en Paraguay. Pp. 345-358 in Historia de la Mastozoología en Latinoamérica, las Guayanas y el Caribe (Ortega, J., J. L. Martínez, and D. G. Tirira, eds.). Editorial Murciélago Blanco y Asociación Ecuatoriana de Mastozoología. Quito, Ecuador, and México City, Mexico.

Lynch Alfaro, J. W., J. S. E. Silva, JR., and A. B. Rylands. 2012 a. How different are robust and gracile capuchin monkeys? An argument for the use of Sapajus and Cebus. American Journal of Primatology 74:273-286.

Marques-Aguiar, S. A. 2008. Genus Artibeus Leach, 1921. Pp. 301-321 in Mammals of South America Volume 1, Marsupials, xenarthans, shrews and bats (Gardner, A. L., ed.). University of Chicago Press. Chicago, U. S. A.

Martínez, R., E. Torres, M. Nieves, V. Zapkievich, S. Rodriguez, A. SCHININI, M. AscurRa, ANd M. D. Mudry. 2004. Genetic variability in two captive colonies of Cebus apella paraguayanus (Primates: Platyrrhini) from eastern Paraguay. Caryologia 57:332-336.

Martínez-Lanfranco, J. A., D. Flores, J. P. Jayat, and G. D’Elía. 2014. A new species of lutrine opossum, genus Lutreolina Thomas (Didelphidae), from the South American Yungas. Journal of Mammalogy 95:225-240.

Matayoshi, T., Howlin, E., Nasazzi, N., Nagle, C., Gadow, E., and SeuÁneZ, H. N. 1986. Chromosome studies of Cebus apella: the standard karyotype of Cebus apella paraguayanus Fischer, 1829. American Journal of Primatology 10:185-193.

Mayer, J. J., AND P. N. Brandt. 1982. Identity, distribution and natural history of the peccaries, Tayassuidae. Pp. 433-456 in
Mammalian biology in South America (Mares, M. A., and $\mathrm{H}$. H. Genoways, eds.). Special Publication Series, Pymatuning Laboratory of Ecology 6:1-539.

MAYeR, J. J., AND R. M. Wetzel. 1986. Catagonus wagneri. Mammalian Species 259:1-5.

McCulloch, E., And R. D. Stevens. 2011. Rapid development and screening of microsatellite loci for Artibeus lituratus and their utility for six related species within Phyllostomidae. Molecular Ecology Resources 11:903-913.

McCulloch, E., J. S. Tello, A. Whitehead, C. M. J. Rolón-Mendoza, M. C. D. Maldonado-Rodriguez, and R. D. Stevens. 2013. Fragmentation of Atlantic Forest has not affected gene flow of a widespread seed-dispersing bat. Molecular Ecology 22:4619-4633.

McLellan, L. J., AND K. F. KoOpman. 2008. Subfamily Carolliinae Miller 1924. Pp. 208-218 in Mammals of South America Volume 1, Marsupials, xenarthans, shrews and bats (Gardner, A. L., ed.). The University of Chicago Press. Chicago, U. S. A. MeritT, D. A. 1973. Some observations on the maned wolf Chrysocyon brachyurus in Paraguay. Zoologica 58:53.

MerITT, D. A. 2010. Use of apple snails (Pomacea canaliculata) by Chacoan peccary (Catagonus wagneri). Der Zoologische Garten 7:175-178.

Moratelli, R., AND D. E. Wilson. 2013. Distribution and natural history of Myotis lavali (Chiroptera, Vespertilionidae). Journal of Mammalogy 94:650-656.

Moratelli, R., L. IdÁrRAga, And D. E. Wilson. 2015. Range extension of Myotis midastactus (Chiroptera, Vespertilionidae) to Paraguay. Biodiversity Data Journal 3:e5708, doi: 10.3897/ BDJ.3.e5708.

Mudry, D. E., M. D. Pargament, and I. R. Slavutsky. 1987. Banding Patterns of the Chromosomes of Cebus apella: Comparative studies between specimens from Paraguay and Argentina. Primates 28:111-117.

Mudry, D. E., N. Nives, and A. D. Bolzán. 2007. Chromosomal localization of the telomeric (TTAGGG)n sequence in eight species of New World primates (Neotropical Primates, Platyrrhini). Cytogenetic and Genome Research 119:221-224. Murray, J. L., AND G. L. Gardner. 1997. Leopardus pardalis. Mammalian Species 548:1-10.

MYERS, P. 1982. Origins and affinities of the mammal fauna of Paraguay. Pp. 85-93 in Mammalian biology in South America (Mares, M. A., and H. H. Genoways, eds.). Special Publication Series, Pymatuning Laboratory of Ecology 6:1-539.

Myers, P., A. Taber, and I. Gamarra de Fox. 2002. Mamíferos de Paraguay. Pp. 453-502 in Diversidad y Conservación de los Mamíferos Neotropicales (Ceballos, G., and J. A. Simonetti, eds.). CONABIO-UNAM. México City, Mexico.

Neris, N. N. 1998. Los mamíferos de Paraguay. Pp. 51-64 in La diversidad biológica de Iberoamérica Vol. III (Halffter, G., ed.). Acta Zoológica Mexicana, Nueva Serie, Volumen especial.

Owen, R. D., P. Smith, C. López-González, and M. Ruiz Díaz. 2014. First records of two species of bats (Mammalia: Chiroptera: Emballonuridae and Phyllostomidae) from Paraguay. Boletín de la Sociedad Zoológica del Uruguay 23:67-73.

Padula P., V. P. Martínez, C. Bellomo, S. Maidana, J. San Juan, P. Tagliaferri, S. Bargardi, C. Vázquez, N. Coluccl, J. Estévez, and M. Almiron. 2007. Pathogenic hantaviruses, Northeastern Argentina and Eastern Paraguay. Emerging Infectious Diseases 13:1211-1214. 
Pardiñas, U. F. J., P. Teta, D. Alvarado-Serrano, L. Geise, J. P. Jayat, P. E. Ortiz, P. R. Gonçalves, and G. D’Elía. 2015. Genus Akodon Meyen, 1833. Pp. 144-204 in Mammals of South America, Volume 2, Rodents (Patton, J. L., U. F. J. Pardiñas and G. D'Elía. eds.). The University of Chicago Press. Chicago, U. S. A.

Pardiñas, U. F. J., P. Teta, J. Salazar-Bravo, P. Myers, and C. A. GalLIARI. 2016. A new species of arboreal rat, genus Oecomys (Rodentia, Cricetidae) from Chaco. Journal of Mammalogy 97:1177-1196.

Pargament, M. M., And I. R. Slavutsky. 1987. Banding patterns of the chromosomes of Cebus apella: Comparative studies between specimens from Paraguay and Argentina. Primates 28:111-117.

Patton, J. L. 2015. Family Cuniculidae G. S. Miller and Gidley, 1918. Pp. 726-733 in Mammals of South America, Volume 2, Rodents (Patton, J. L., U. F. J. Pardiñas, and G. D'Elía. eds.). The University of Chicago Press. Chicago, U. S. A.

Patton, J. L. AND M. N. F. DA Silva. 1997. Definition of species of pouched four-eyed opossums (Didelphidae, Philander). Journal of Mammalogy 78:90-102.

PatTon, J. L., AND M. N. F. DA SILVA. 2008. Genus Philander Brisson, 1762. Pp. 27-35 in Mammals of South America Volume 1: Marsupials, xenarthans, shrews and bats. (Gardner, A. L., ed.). University of Chicago Press. Chicago, U. S. A.

Patton, J. L., and L. H. Emmons. 2015. Family Dasyproctidae Bonaparte, 1838. Pp. 733-762 in Mammals of South America, Volume 2, Rodents (Patton, J. L., U. F. J. Pardiñas, and G. D'Elía, eds.). The University of Chicago Press. Chicago, U. S. A.

Patton, J. L., U. F. J. Pardiñas, ANd G. D'Elía (eds.). 2015. Mammals of South America. Volume 2, Rodents. The University of Chicago Press. Chicago, U. S. A.

Percequillo, A. R. 2015. Genus Sooretamys Weksler, Percequillo, and Voss, 2006. Pp. 451-454 in Mammals of South America, Volume 2, Rodents (Patton, J. L., U. F. J. Pardiñas, and G. D'Elía, eds.). The University of Chicago Press. Chicago, U. S. A.

Percequillo, A. R., E. Hingst-Zaher, and C. R. Bonvicino. 2008. Systematic review of genus Cerradomys Weksler, Percequillo and Voss, 2006 (Rodentia: Cricetidae: Sigmodontinae: Oryzomyini), with description of two new species from eastern Brazil. American Museum Novitates 3622:1-46.

Pickles, R. S. A., J. J. Groombridge, V. D. Zambrana Rojas, P. Van Damme, D. Gottelli, S. Kundu, and R. Bodmer. 2011. Evolutionary history and identification of conservation units in the giant otter Pteronura brasiliensis. Molecular Phylogenetics and Evolution 61:616-27.

PINE, R. H. 1982. Current status of South American Mammalogy. Pp. 27-37 in Mammalian biology in South America (Mares, M. A., and H. H. Genoways, eds.). Special Publication Series, Pymatuning Laboratory of Ecology 6:1-539.

Podtiaguin, B. 1944. Contribuciones al conocimiento de los murciélagos del Paraguay. Revista de la Sociedad Científica del Paraguay 6:25-62.

PresLey, S. J. 2000. Eira barbara. Mammalian Species 636:1-6. PRESLEY, S. J. 2007. Streblid bat fly assemblage structure on Paraguayan Noctilio leporinus (Chiroptera: Noctilionidae): nestedness and species co-occurrence. Journal of Tropical Ecology 23:409-417.

PresLeY, S. J. 2012. Sex based population structure of ectoparasites from Neotropical bats. Biological Journal of the Linnean Society 107:56-66.
Presley, S. J., AND M. R. Willig. 2008. Intraspecific patterns of ectoparasite abundances on Paraguayan bats: effects of host sex and body size. Journal of Tropical Ecology 24:7583.

Presley, S. J., C. L. Higgins, C. López-González, and R. D. Stevens. 2009. Elements of metacommunity structure of Paraguayan bats: multiple gradients require analysis of multiple axes of variation. Oecologia 160:781-793.

Queirolo, D., J. R. Moreira, L. Soler, L. H. Emmons, F. H. Rodrigues, A. A. Pautasso, J. L. Cartes, and V. Salvatori. 2011. Historical and current range of the near threatened maned wolf Chrysocyon brachyurus in South America. Oryx 45:296-303.

Rumbo, M. 2010. Análisis biogeográfico de los mamíferos de Paraguay. Boletín del Museo Nacional de Historia Natural del Paraguay 16:18-29.

Rumiz D. And J. Stallings. 1989. Estado de la primatologia en Paraguay. Boletín de Primatología, 1:37-42.

Rylands, A. B. and R. A. Mittermeier. 2009. Chapter 2: The diversity of the New World primates (Platyrrhini): An annotated taxonomy. Pp. 23-54 in South American Primates, developments in Primatology: progress and prospects. (Garber, P. A., A. Estrada, J.C. Bicca-Marques, E.W. Heymann, and K. B. Strier, eds.). Springer. New York, USA

Rylands, A. B., A. F. Coimbra-Filho, R. A. Mittermeier. 2009. Chapter 2: The systematics and distributions of the marmosets (Callithrix, Callibella, Cebuella, and Mico) and callimico (Callimico) (Callitrichidae, Primates). Pp. 25-61 in The smallest anthropoids, developments in Primatology progress and prospects (Ford, S. M., L. M. Porter, and L. C. Davis, eds.). Springer. New York, U. S. A.

Sainz Ollero, H., F. Suárez Cardons, and M. Vázquez de Castro ONTAÑón. 1989. José Sánchez Labrador y los naturalistas jesuitas del Río de la Plata. Ministerio de obras públicas y urbanismo. Ávila, España.

Salazar-Bravo, J. 2015. Genus Calomys Waterhouse, 1837. Pp. 481-507 in Mammals of South America, Volume 2, Rodents (Patton, J. L., U. F. J. Pardiñas, and G. D'Elía, eds.). The University of Chicago Press. Chicago, U. S. A.

Simmons, N. B. 2005. Chiroptera. Pp. 159-174 in The rise of placental mammals: Origins of the major clades of placental mammals (Rose, K. D., and J. D. Archibald, eds.). Johns Hopkins University Press. Baltimore, U. S. A.

$\mathrm{S}_{\text {MITH, }}$ P. 2012. Assessing the assessment, the relevance of the 2006 Paraguayan mammal Red List to the reality of Xenarthra conservation in 2012. Edentata 13:18-28.

SMIth, P., AND R. D. OWen. 2015. The subgenus Micoureus (Didelphidae: Marmosa) in Paraguay: morphometrics, distributions, and habitat associations. Mammalia 79:463471.

Smith, P. R. D. Owen, K. Atkinson, H. del Castillo, E. NorthcoteSмIтH. 2011. First records of the southern naked-tailed Armadillo Cabassous unicinctus (Linnaeus, 1758) (Xenarthra: Dasypodidae) in Paraguay. Edentata 12:53-57.

Smith, P., H. Pheasey, K. Atkinson, J. Ramakers, and J. Sarvary. 2012. The Didelphimorphia (Didelphidae) of Reserva Natural Laguna Blanca, Departamento San Pedro, Paraguay. Acta Zoológica Lilloana 151:141-153.

Smith, P., R. D. Owen, H. del Castillo, M. Ortiz, and A. Cabrera. 2013 a. Historical and recent records of greater grison Galictis vittata 
in Paraguay, with nomenclatural comments. Small Carnivore Conservation 49:43-47.

SolARI, S. 2010. A molecular perspective on the diversification of short-tailed opossums (Monodelphis: Didelphidae). Mastozoología Neotropical 17:317-333.

Spotorno, A. E., And J. L. Patton. 2015. Superfamily Chinchilloidea Bennett, 1833. Pp. 762-783 in Mammals of South America, Volume 2, Rodents (Patton, J. L., U. F. J. Pardiñas, and G. D’Elía, eds.). The University of Chicago Press. Chicago, U. S. A.

Stallings, J. R. 1984. Notes on the feeding habits of Mazama gouazoubira in the Chaco Boreal of Paraguay. Biotropica 16:155-157.

Stallings, J. R. 1985. Distribution and status of primates in Paraguay. Primate Conservation 6:51-58.

Stallings, J. R. 1986. Notes on the reproductive biology of the grey brocket deer (Mazama gouazoubira) in Paraguay. Journal of Mammalogy 67:172-175.

Stallings, J. R., and R. A. Mittermeier. 1983. The black-tailed marmoset (Callithrix argentata melanura) recorded from Paraguay. American Journal of Primatology 4:150-163.

Stein B. R, and J. L. Patton. 2008. Genus Chironectes Illiger, 1811. Pp. 14-17 in Mammals of South American Volume 1: Marsupials, xenarthans, shrews and bats (Gardner, A. L., ed.). University of Chicago Press. Chicago, U. S. A.

Stevens, R. D. 2001. Twinning in the big fruit-eating bat Artibeus lituratus (Chiroptera: Phyllostomidae) from eastern Paraguay. Mammalian Biology 66:178-180.

Stevens, R. D., and H. N. Amarilla-Stevens. 2012. Seasonal environments, episodic density compensation and dynamics of structure of chiropteran frugivore guilds in Paraguayan Atlantic forest. Biodiversity and Conservation 21:267-279.

Stevens, R. D., M. R. Willig, and I. Gamarra de Fox. 2004. Comparative community ecology of bats from eastern Paraguay: taxonomic, ecological, and biogeographic perspectives. Journal of Mammalogy 85:698-707.

Stevens, R. D., C. López-González, and S. J. Presley. 2007. Geographical ecology of Paraguayan bats: spatial integration and metacommunity structure of interacting assemblages. Journal of Animal Ecology 76:1086-1093.

Stevens, R. D., C. López-González, E. S. MCCulloch, F. Netto, and M. L. Ortiz. 2010. Myotis levis (Geoffroy Saint-Hilaire) indeed occurs in Paraguay. Mastozoología Neotropical 17:195-200.

Stevens, R. D., M. E. Johnson, and E. S. MCCulloch. 2016. Geographic variation of wing morphology of great fruiteating bats (Artibeus lituratus): environmental, genetic and spatial correlates of phenotypic differences. Biological Journal of the Linnean Society 118:734-744.

Sutherland-Smith, M., J. M. Campos, C. Cramer, C. Thorstadt, W. TOONE, AND P. J. MorRIS. 2004. Immobilization of Chacoan peccaries (Catagonus wagneri) using medetomidine, telazol, and ketamine. Journal of Wildlife Diseases 40:731-736.

TABER, A. B. 1990. El taguá, un plan de acción para su conservación en el Paraguay. Editora Litocolor. Asunción, Paraguay.

TABER, A. B. 1991. The status and conservation of the Chacoan peccary in Paraguay. Oryx 25:147-155.

TABER, A. B. 1993. 2.4 The chacoan peccary (Catagonus wagneri). Pp. 22-29 in Pigs, peccaries and hippos, status, survey, and conservation action plans (Oliver, W. L. R., ed.). IUCN. Gland, Switzerland.
Taber, A. B., C. P. Doncaster, N. N. Neris, and F. H. Colman. 1993. Ranging behavior and population dynamics of the Chacoan peccary, Catagonus wagneri. Journal of Mammalogy 74:43-454.

Taber, A. B., C. P. Doncaster, N. N. Neris, and F. H. Colman. 1994. Ranging behaviour and activity patterns of two sympatric peccaries, Catagonus wagneri and Tayassu tajacu, in the Paraguayan Chaco. Mammalia 58:61-72.

Taber, A. B., A. J. Novaro, N. N. Neris, and F. H. Colman. 1997. The food habits of sympatric jaguar and puma in the Paraguayan Chaco. Biotropica 29:204-213.

Teta, P., G. D’Elía, D. Flores, and N. U. de la Sancha. 2009. Diversity and distribution of the mouse opossums of the genus Thylamys (Didelphimorphia, Didelphidae) in northeastern and central Argentina. Gayana 73:180-199.

Teta, P., U. F. J. Pardiñas, and G. D'Elía. 2015. Genus Thaptomys Thomas, 1916. Pp. 277-279 in Mammals of South America, Volume 2, Rodents (Patton, J. L., U. F. J. Pardiñas, and G. D’Elía, eds.). The University of Chicago Press. Chicago, U. S. A.

Timm, R. M., J. L. Cartes, M. Ruíz-Díaz, R. Zárate, And R. H. Pine. 2015. Distribution and ecology of squirrels (Rodentia: Sciuridae) in Paraguay, with first country records for Sciurus ignitus. The Southwestern Naturalist 60:121-127.

Toone, W., And M. Wallace. 2002. The Giant Chacoan Peccary: an outstanding example of adaptation to a subtropical dryland ecosystem. Biodiversity 3:28-31.

Toone, W., J. Campos, and M. Wallace. 2003. Release of radiocollared giant Chacoan peccary in Paraguay. Re-introduction News 22:34-36.

Torres, J. C., P. Teta, and N. U. de la Sancha. 2014. Presas del búho campestre (Asio flammeus) en un agroecosistema subtropical de Paraguay. Nuestras Aves 59:24-27.

Trigo, T. C., T. R. Freitas, G. Kunzler, L. Cardoso, J. C. Silva, W. E. Johnson, S. J. O'Brien, S. L. Bonatto, And E. Eizirik. 2008. Inter-species hybridization among Neotropical cats of the genus Leopardus, and evidence for an introgressive hybrid zone between $L$. geoffroyi and L. tigrinus in southern Brazil. Molecular Ecology 17:4317-4333.

Trigo, T. C., A. Schneider, T. G. de Oliveira, L. M. Lehugeur, L. Silveira, T. R. O. Freitas, AND E. EIzIRIK. 2013. Molecular data reveal complex hybridization and a cryptic species of Neotropical wild cat. Current Biology 23:1-6.

Velazco, P. M., and B. D. Patterson. 2013. Diversification of the yellow-shouldered bats, genus Sturnira (Chiroptera, Phyllostomidae), in the New World tropics. Molecular Phylogenetics and Evolution 68:683-698.

Velázquez, M. C., and F. Ramírez Pinto. 2014 (2015). Guía de los mamíferos de la Reserva Natural Tapytá. Fundación Moisés Bertoni. Asunción, Paraguay.

Villalba, L., And C. Bonacic. 2006. Rediscovery of the Guanaco in the Paraguayan Chaco. The Camelid Quarterly March:1-2.

VisloвокоVA, I. A. 2013. On the Origin of Cetartiodactyla: Comparison of data on evolutionary morphology and molecular biology. Paleontological Journal 47:321-334.

Voss, R. S. 2015. Family Erethizontidae Bonaparte, 1845. Pp. 786-804 in Mammals of South America, Volume 2, Rodents (Patton, J. L., U. F. J. Pardiñas, and G. D'Elía, eds.). The University of Chicago Press. Chicago, U. S. A.

Voss, R. S. And S. A. JAnSA. 2009. Phylogenetic relationships and classification of didelphid marsupials, an extant radiation of 
New World metatherian mammals. Bulletin of the American Museum of Natural History 322:1-177.

Voss, R. S., D. P. LUNDE, AND S. A. JANSA. 2005. On the contents of Gracilinanus Gardner and Creighton, 1989, with the description of a previously unrecognized clade of small didelphid marsupials. American Museum Novitates 3482:1-36.

Voss, R. S., P. Myers, F. Catzeflis, A. Carmignotto, and J. Barreiro. 2009. The six opossums of Félix de Azara: identification, taxonomic history, neotype designations, and nomenclatural recommendations. Pp. 406-433 in Systematic Mammalogy: Contributions in honor of Guy G. Musser (Voss, R. S, and M. D. Carleton, eds.). Bulletin of the American Museum of Natural History 331:406-433.

Weiler, A., ANd K. Núñez. 2012. Desafíos para la conservación del tatú carreta (Priodontes maximus) en el Chaco Paraguayo. Reportes Científicos de la FACEN 3:5-13.

Weksler, M., AND C. R. Bonvicino. 2005. Taxonomy of pigmy rice rats (genus Oligoryzomys, Rodentia: Sigmodontinae) of the Brazilian Cerrado, with the description of two new species. Arquivos do Museu Nacional, Rio de Janeiro 63:113-130.

Weksler, M., and C. R. Bonvicino. 2015. Genus Oligoryzomys Bangs, 1900. Pp. 417-438 in Mammals of South America, Volume 2, Rodents (Patton, J. L., U. F. J. Pardiñas, and G. D'Elía, eds.). The University of Chicago Press, Chicago, U. S. A.

Weksler, M., A. R. Percequillo, and R. S. Voss. 2006. Ten new genera of Oryzomyine rodents (Cricetidae: Sigmodontinae). American Museum Novitates 3537:1-28.

WetzeL, R. M. 1980. Revision of the naked-tailed armadillo, genus Cabassous McMurtrie. Annals of Carnegie Museum 49:323-357.

Wetzel, R. M. 1985. Taxonomy and distribution of armadillos, Dasypodidae. Pp. 23-48 in The evolution and ecology of armadillos, sloths, and vermilinguas (Montgomery, G. G., ed.). Smithsonian Institution Press. Washington D.C., U. S. A.

Wetzel, R. M., R. E. Dubos, R. L. Martin, and P. Myers. 1975. Catagonus, an "extinct" peccary alive in Paraguay. Science 189:379-381.

Wetzel, R. M., A. L. Gardner, K. H. Redford, and J. F. Eisenberg. 2008. Family Dasypodidae Gray, 1821. Pp. 157-177 in Mammals of South America Volume 1, Marsupials, xenarthans, shrews and bats (Gardner, A. L. ed.). The University of Chicago Press. Chicago, U. S. A.

Williams, S. L., AND H. H. Genoways. 2008. Subfamily Phyllostominae Gray, 1825. Pp. 255-300 in Mammals of South America Volume 1, Marsupials, xenarthans, shrews and bats (Gardner, A. L., ed.). The University of Chicago Press. Chicago U. S. A.

Willig, M. R., S. J. Presley, R. D. Owen, and C. López-González. 2000. Composition and structure of bat assemblages in Paraguay: A subtropical-temperate interface. Journal of Mammalogy 81:386-401.

Wilson, D. E. 2008. Genus Myotis Kaup, 1829. Pp. 468-481 in Mammals of South America Volume 1, Marsupials, xenarthans, shrews and bats (Gardner, A. L., ed.). The University of Chicago Press. Chicago, U. S. A.

Wilson, D. E. And D. M. Reeder. 2005. Mammal Species of the World, a taxonomic and geographic reference. 3rd ed. Johns Hopkins University Press. Baltimore, U. S. A.

Wozencraft, W. C. 2005. Order Carnivora. Pp. 532-628 in Mammal Species of the World: a taxonomic and Geographic
Reference, 3rd edition (Wilson, D. E., and D. M. Reeder, eds.). Johns Hopkins University Press. Baltimore, U. S. A.

YahnKe, C. J., J. Unger, B. Lohr, D. A. Meritt, And W. Heuschele. 1997. Age specific fecundity, litter size, and sex ratio in the Chacoan peccary (Catagonus wagneri). Zoo Biology 1:301-307.

YahnKe, C. J., P. L. Meserve, T. G. Ksiazek, And J. N. Mills. 2001. Patterns of infection with Laguna Negra virus in wild populations of Calomys laucha in the central Paraguayan Chaco. American Journal of Tropical Medicine and Hygiene 65:768-776.

Zuercher, G. L., and F. R. D. Villalba. 2002. Records of Speothos venaticus Lund, 1842 (Carnivora, Canidae) in eastern Paraguay. Mammalian Biology 67:185-187.

Zuercher, G. L., P. S. Gipson, AND K. Hill. 2001. A predator-habitat assessment for felids in the inland Atlantic Forest of Eastern Paraguay: a preliminary analysis. Endangered Species Update 18:115-119.

Zuercher G. L., P. S. Gipson, and G. C. Stewart. 2003. Identification of carnivore feces by local peoples and molecular analyses. Wildlife Society Bulletin 31:961-970.

Zuercher G. L., P. S. Gipson, AND O. Carrillo. 2005. Diet and habitat associations of bush dogs Speothos venaticus in the Interior Atlantic Forest of eastern Paraguay. Oryx 39:86- 89.

Associated editor: Robert Owen

Submitted: April 2, 2017; Reviewed: May 17, 2017;

Accepted: July 10, 2017; Published on line: September 12, 2017. 
MAMMALS OF PARAGUAY

260 THERYA Vol. 8 (3): 241-260 